\title{
25. MARINE CRETACEOUS PALYNOLOGY OF SITE 361, DSDP LEG 40, OFF SOUTHWESTERN AFRICA
}

\author{
Roger J. Davey,' Institute of Geological Sciences, Leeds, England
}

\begin{abstract}
Relatively rich marine playnomorph assemblages, consisting of dinocysts and acritarchs, occur in the majority of the 35 Cretaceous cores investigated from Site 361. The Early Cretaceous, Cores 48 to 27, is considered to be of Aptian age with the early-late Aptian boundary lying between Samples 33-3, 117-118 cm and 32-2,117$119 \mathrm{~cm}$. The Aptian dinocyst assemblage is comparable to that found in Australia and Europe. The Late Cretaceous, Cores 24 to 13 , is more difficult to date because of the poor similarity of the assemblages with those from Europe; they are more comparable to the Australian assemblages where, unfortunately, the precise stratigraphic ranges of species are mainly unknown. Cenomanian was not identified and the succession begins in the Turonian. The top of the Turonian is tentatively drawn above Core 21 and the remainder of the Cretaceous sequence is assigned a Senonian-early Maestrichtian age. Normal marine conditions prevailed in the photic zone during the deposition of the above sediments; however, during most of the Aptian and Turonian, bottom conditions appear to have been anaerobic. During the Aptian, in particular, run-off from the surrounding landmasses was great and considerable amounts of terrestrially derived organic matter were transported to the site of deposition resulting in the accumulation of organically rich sediments; sapropel is abundant and, in this case, is probably land derived. Systematics are kept to a minimum and only four new taxa are proposed-A sustralisphaera gen. nov.; $A$. verrucosa sp. nov., Aiora perforare sp. nov., and Cyclonephelium distinctum subsp. longispinatum subsp. nov.
\end{abstract}

\section{INTRODUCTION}

Site $361\left(35^{\circ} 03.97^{\prime} \mathrm{S}, 15^{\circ} 26.91^{\prime} \mathrm{E}\right)$ is located near the base of the southwest African continental rise (water depth $4549 \mathrm{~m})$ at approximately 180 miles westsouthwest of Cape Town, South Africa. (Figure 1) A practically complete Eocene to Aptian section was penetrated to a depth of 1314 meters and 49 cores were taken. Of these 12 to 49 inclusive are of Cretaceous age.

Palynologic slides prepared from 35 samples (see below), representing 29 cores, were examined during this study for their marine palynomorph (dinocyst and acritarch) content. The slides were, in part, made available for examination by Mr. I.R. McLachlan who also provided wet residues from which additional slides were made. $\mathrm{He}$ and Elizabeth Pieterse, in a paper entitled "Preliminary palynological results: Site 361, Leg 40, Deep Sea Drilling Project" in the present volume report on all the components of the organic residues, principally to elucidate paleoecological conditions within the depositional basin. The present study involves a more detailed account and description of the dinocysts and acritarchs and supercedes the

\footnotetext{
'By permission of the Director, Institute of Geological Sciences,
} Great Britain.

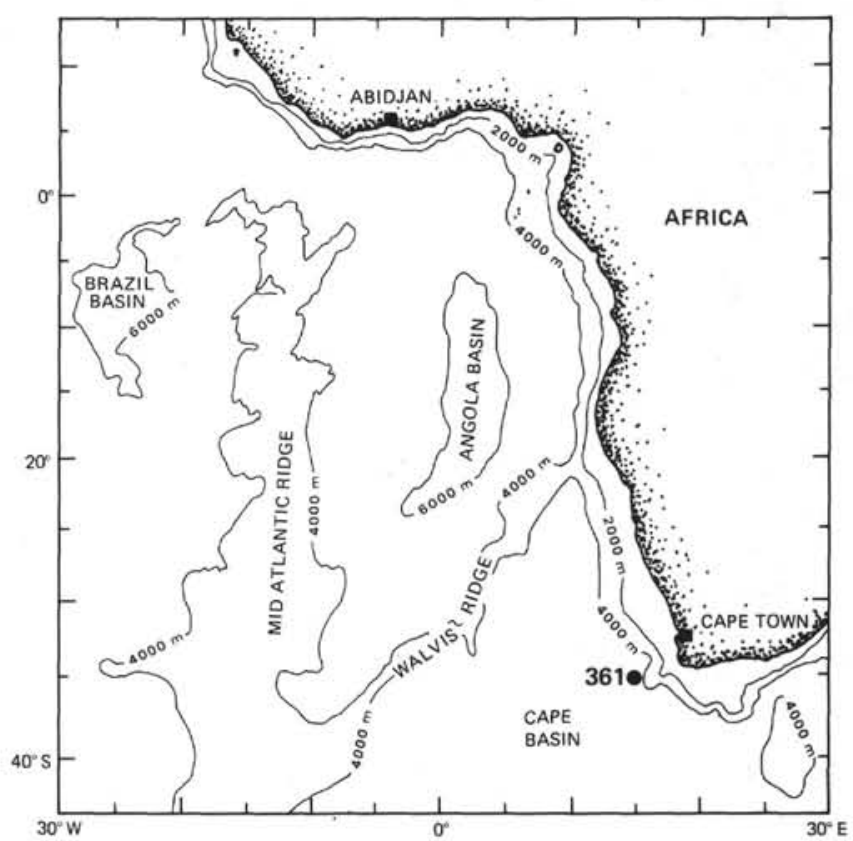

Figure 1. Location of DSDP Leg 40 Site 361.

provisional identifications of McLachlan and Pieterse. Three additional samples-29-3, 48-50 cm, 38-2, 38-40 
$\mathrm{cm}$, and 44-2,111-113 $\mathrm{cm}$ - were subsequently acquired from SOEKOR and incorporated into the study.

All slides of type material with the prefix MPK and slides labeled CSA are housed in the Palynological Collection, Institute of Geological Sciences, Leeds, England. The slides borrowed from SOEKOR are now in their palynology laboratories, Johannesburg, South Africa. The co-ordinates of all specimens are from the Zeiss rotating and centering mechanical stage $50 / 75$, number 4896 472, IGS, Leeds.

\section{SAMPLES EXAMINED}

Table 1 lists the samples examined during the present study. The SOEKOR numbers refer to samples also analyzed by McLachlan and Pieterse (this volume).

\section{PALYNOLOGICAL RESULTS}

\section{General Discussion}

On the basis of this investigation the Cretaceous sequence can be divided into two parts, one of Early Cretaceous and one of Late Cretaceous age. The palynological residue from the Early Cretaceous is dominated by sapropelic organic matter, coarse

TABLE 1

Samples Examined

\begin{tabular}{ccl}
\hline $\begin{array}{c}\text { l.G.S. } \\
\begin{array}{c}\text { Sample No. } \\
\text { (CSA) }\end{array}\end{array}$ & $\begin{array}{c}\text { SOEKOR Palynology } \\
\text { Sample No. }\end{array}$ & $\begin{array}{c}\text { Sample } \\
\text { (Interval } \\
\text { in cm) }\end{array}$ \\
\hline 1725 & 4978 & $13-1,123-125$ \\
1726 & 4983 & $17-2,51-53$ \\
1727 & 4984 & $18-2,140-141$ \\
1728 & 4985 & $19-2,143-145$ \\
1729 & 4986 & $19-4,91-92$ \\
1730 & 4987 & $20-2,144-146$ \\
1731 & 4988 & $21-2,131-133$ \\
1732 & 4989 & $22-2,92-94$ \\
1733 & 4990 & $23-2,61-64$ \\
1734 & 4991 & $24-2,96-98$ \\
1735 & 4993 & $27-2,119-121$ \\
1736 & 4995 & $28-6,115-117$ \\
1737 & & $29-3,48-50$ \\
1738 & 4997 & $31-4,129-131$ \\
1739 & 4998 & $32-2,117-119$ \\
1740 & 5000 & $33-3,117-118$ \\
1741 & 5001 & $34-2,60-62$ \\
1742 & 5002 & $35-2,130-132$ \\
1743 & 5003 & $35-3,50-52$ \\
1744 & 5004 & $36-1,103-105$ \\
1745 & 5005 & $36-2,136-138$ \\
1746 & 5006 & $36-3,77-79$ \\
1747 & 5007 & $37-2,129-131$ \\
1748 & & $38-2,38-40$ \\
1749 & 5010 & $40-2,87-89$ \\
1750 & 5011 & $40-3,99-101$ \\
1751 & 5012 & $41-1,90-92$ \\
1752 & 5014 & $41-3,53-55$ \\
1753 & 5017 & $43-2,116-118$ \\
1754 & 5018 & $43-3,12-13$ \\
1755 & & $44-2,111-113$ \\
1756 & 5019 & $45-1,134-136$ \\
1757 & 5022 & $46-2,124-125$ \\
1758 & 5023 & $47-1,128-130$ \\
1759 & 5024 & $48-2,134-136$ \\
\hline & & \\
& & \\
173 & &
\end{tabular}

terrestrially derived plant debris and sporomorphs; marine palynomorphs represent less than $5 \%$ of the palynomorph assemblage and are sometimes apparently absent. However, marine species, although low in abundance, are often quite high in diversity and more than 30 species may be present in an assemblage. The marine palynomorph assemblage is unusual in that acritarchs are typically abundant and, in some instances, outnumber the dinocysts. Microforaminifers occur in most samples.

The Late Cretaceous palynologic residues contain markedly less sapropelic organic matter-none at all in the younger samples-still with a considerable amount of terrestrially derived plant debris but fewer sporomorphs; marine palynomorphs, particularly dinocysts, are now generally common and compose up to $30 \%$ of the palynomorph assemblage. The number of marine species per sample, however, remains broadly similar to that found in the Early Cretaceous. Microforaminifers continue to be present but the acritarchs are considerably less abundant and disappear entirely higher in the sequence.

\section{Stratigraphic Discussion}

The majority of the marine palynomorphs recovered have been previously reported from sediments of similar age in other parts of the world, notably Australia and Northwest Europe and, to a lesser extent, North America. Literature on Cretaceous assemblages from southern Africa, South America, India, and Antarctica, however, is virtually nonexistent and so comparison with these and neighboring regions is impossible. This emphasizes the necessity for a detailed stratigraphic description of the present assemblages and is the reason for the morphologic and taxonomic comments made in part 2 of the systematics section.

The Cretaceous assemblages most closely resemble those described in many Australian publications and particularly those from Western Australia. Their stratigraphic ranges there, however, are not accurately known because most of the assemblages come from poorly dated boreholes. Thus only tentative dates can be obtained by comparison even though assemblage evolution appears to be almost identical in the two regions.

The European Cretaceous assemblages are the better known even though much still remains unpublished. The Early Cretaceous dinocyst assemblage of Site 361 is remarkably similar to that known to occur in France where the most detailed work has taken place. The Late Cretaceous assemblages are less similar because of the presence of several distinctive Australian forms which are not found in Europe. The stratigraphic ranges of species are particularly well known in France and England and dating of the Site 361 assemblages is effected mainly by data from these two countries.

There appears to be a relatively large difference between the Site 361 assemblages and those of comparable ages from North America, principally Canada, and detailed comparison leads to very few meaningful stratigraphic conclusions. 


\section{Cores 48 to 27: Aptian}

The marine palynomorph assemblage in these cores consists of dinocysts and acritarchs, the vast majority of which also occur in Europe and Australia (see Figures 2, 3). Only two of the dinocyst species, Dingodinium cerviculum Cookson and Eisenack (1958) and "Canningia" ringnesii Manum and Cookson (1964) have not, as yet, been reported from Europe. Acritarchs typically outnumber the dinocysts and consist mainly of long-ranging species which are indicative of a special and characteristic marine environment rather than a certain stratigraphic level (see Paleoecological Considerations).

The dinocyst assemblage as a whole is typical of the European Aptian (Davey and Verdier, 1974) although several of the characteristic and stratigraphically restricted European species are absent. Davey and Verdier (1974) indicate that the basal Aptian is characterized by the incoming of Aptea polymorpha Eisenack, 1958, Cyclonephelium tabulatum Davey and Verdier, 1974, and Meiourogonyaulax psoros Davey and Verdier, 1974, and the appearance of Protoellipsodinium spinocristatum Davey and Verdier, 1971, during the early Aptian. None of these species were found during the present study, and of these four species only $P$. spinocristatum has been reported from Australia (Morgan, 1975). In addition the marker species for the European Barremian (Milliond, 1969; Davey, 1974), Pseudoceratium pelliferum Gocht, 1957, and Muderongia staurota Sarjeant, 1966c, are also absent. Hence it is on rather negative evidence that the base of Site 361 is dated as Aptian; the possible presence of preAptian strata cannot be completely dismissed.

Higher in the Early Cretaceous sequence several species are stratigraphically important and include, in alphabetical order, those listed below. It should be noted that much of the subsequent stratigraphic discussion is based on Davey and Verdier's 1974 study of the type Aptian (France).

1) Achomosphaera neptuni (Eisenack, 1958) and $A$. cf. neptuni of Davey and Verdier (1974). These occur spasmodically in the French Aptian but not in the Albian. The latter form last occurs in Core 27.

2) Cauca parva (Alberti, 1961) has a first stratigraphic occurrence within the late Aptian of France, and in Core 32.

3) Chlamydophorella huguonioti (Valensi, 1955a) comb. nov. has a first stratigraphic occurrence at the base of the late Aptian in France, and in Core 32.

4) Dingodinium albertii Sarjeant, 1966c, and D. cerviculum. The taxonomic controversy surrounding these two species is discussed in the Systematics Section. In France the genus ranges to the top of the Aptian, but has never been observed in the Albian (Davey and Verdier, 1971; Verdier, 1975); it ranges to the top of the Early Cretaceous (Core 27) at Site 361. The distribution of $D$. cerviculum in Australia was discussed by Haskell (1969) who concluded that its top stratigraphic occurrence coincided with the top of Dettmann's (1963) Speciosus Assemblage Zone and with the top of the Aptian. Burger (in preparation) erects the $D$. cerviculum zone and regards it as Aptian (to ?Barremian) age. Burger's succeeding zone in the succession is that of Pseudoceratium turneri Cookson and Eisenack, 1958, a species which does not occur at Site 361 , and this is considered to be of early to middle Albian age. D. cerviculum does occur rarely in this younger zone but, discussing these occurrences, Burger says "many of the specimens found are suspected to be of secondary (recycled) origin." Finally, relatively rare specimens of $D$. cerviculum have been reported from the Albian of Canada by Singh (1971) and Brideaux (1971). These Canadian occurrences are reminiscent of the younger Australian occurrences and suggest that in certain regions Dingodinium did linger on into the Albian.

5) Kleithriasphaeridium simplicispinum (Davey and Williams, 1966b). In the type Aptian this species has a top stratigraphic occurrence within the late Aptian; it last occurs in Core 32.

6) Muderongia cf. staurota Sarjeant, 1966c, of Davey and Verdier, 1974. This form extends into the earlytype Aptian and is the only Muderongia species to range into post-Barremian strata in Europe; it occurs rarely in many of the Early Cretaceous cores. Muderongia $\mathrm{cf}$. $M$. crucis Neale and Sarjeant, 1962, of Burger (in preparation) is probably equivalent to $M$. cf. staurota and, as with $D$. cerviculum, Burger reports that it occurs rarely up into the early to middle Albian of Australia.

7) Muderongia tetracantha (Gocht, 1957) occurs only in Core 32; in Europe it has been reported from the Hauterivian of Germany (Gocht, 1957) and the early Barremian of England (Sarjeant, 1966c; Davey, 1974). Haskell (1969) considers that the top stratigraphic occurrence of $M$. tetracantha coincides with the top occurrence of $D$. cerviculum and the top of the Aptian. Burger (in preparation) however finds it associated with $M$. cf. staurota (as $M$. cf. $M$. crucis) and D. cerviculum in the early to middle Albian.

8) Palaeoperidinium cretaceum Pocock, 1962, first appears strongly at the top of the early Aptian in France and only occurs in Core 27 at Site 361.

9) Subtilisphaera ventriosa (Alberti, 1959) has only previously been reported from the so-called early Aptian of Germany by Alberti (1959) in borehole Werle 3 (Westmecklenberg). However, because of contamination, reworking and/or caving, no definite age can be assigned to the reported dinocyst assemblage.

From the above stratigraphic discussions, it may be concluded that, at the present time, the most reliable stratigraphic indices within the Aptian at Site 361 appear to be Chlamydophorella huguonioti and Kleithriasphaeridium simplicispinum. These suggest that the base of the upper Aptian is between Samples 33-3, $117-118 \mathrm{~cm}$ and $32-2,117-119 \mathrm{~cm}$. The occurrence of Dingodinium and Achomosphaera cf. neptuni in Core 27, and the distribution of certain other species discussed above in the sequence, strongly suggests that it is Aptian in age.

\section{Cores 26 and 25: Age Indeterminate}

These cores consist mainly of reddish shales and interbedded siltstones; these are invariably palynologically barren. McLachlan and Pieterse (this volume) 


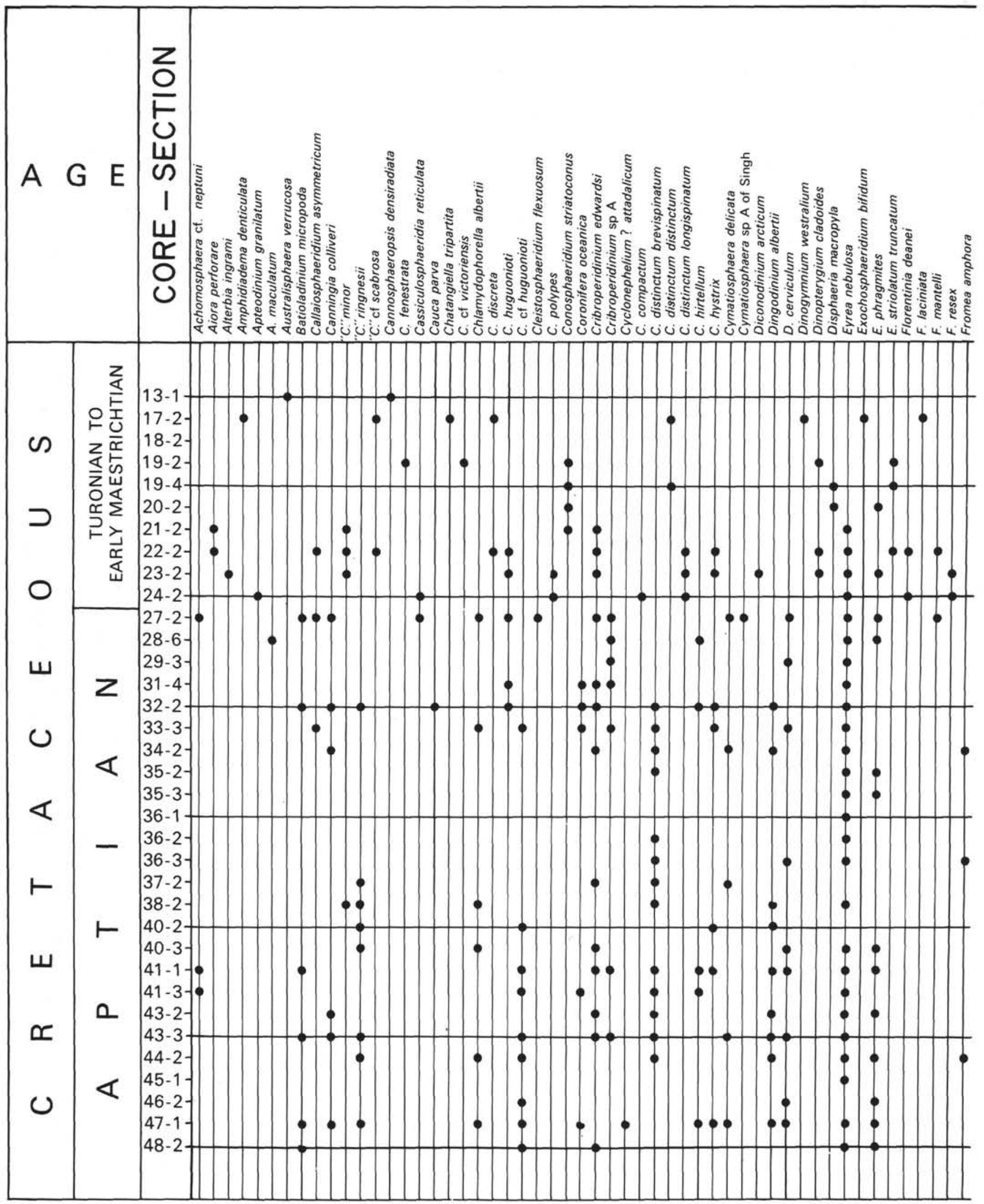

Figure 2. Distribution chart of marine palynomorphs of Cretaceous age from Site 361. 


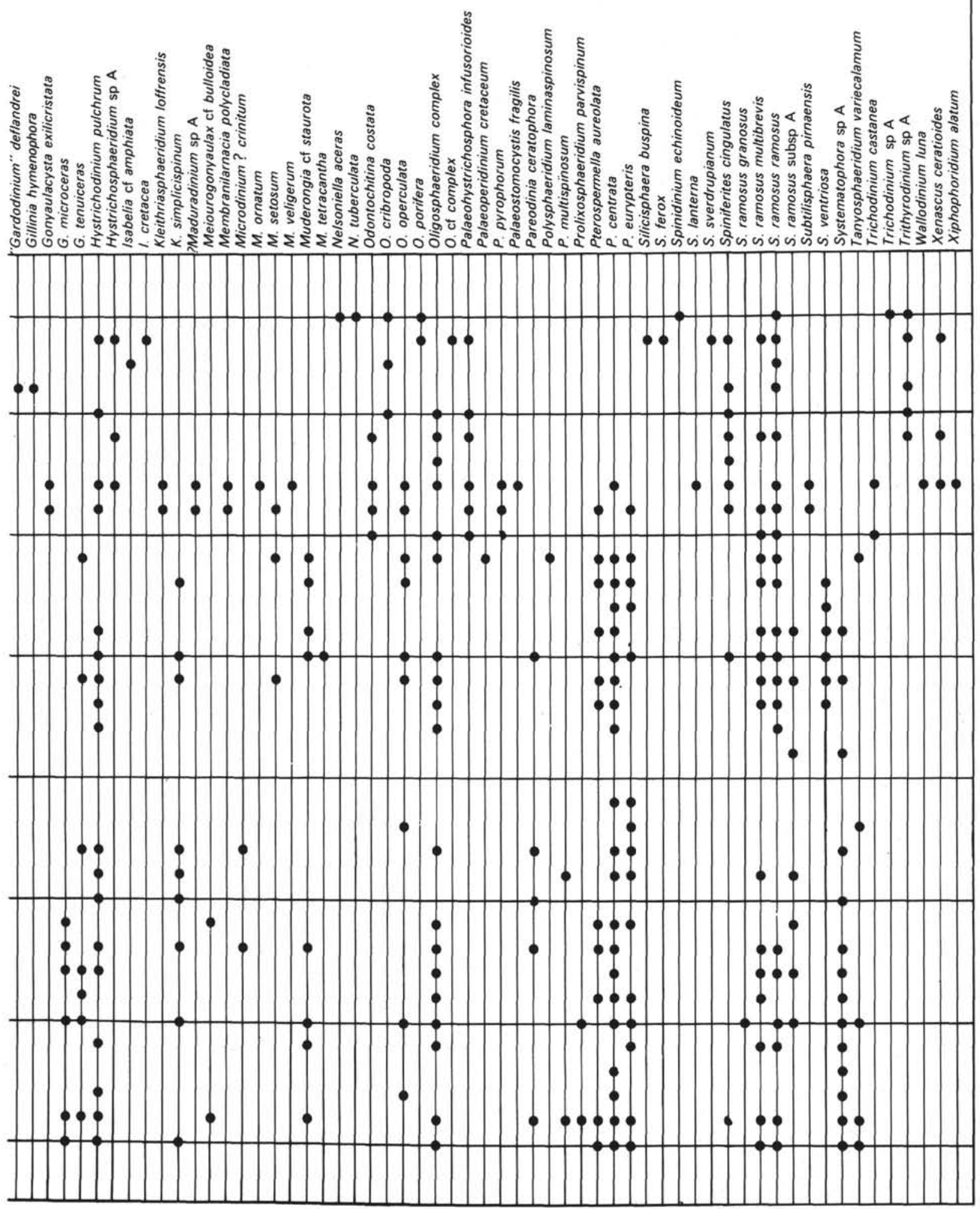

Figure 2. (Continued). 


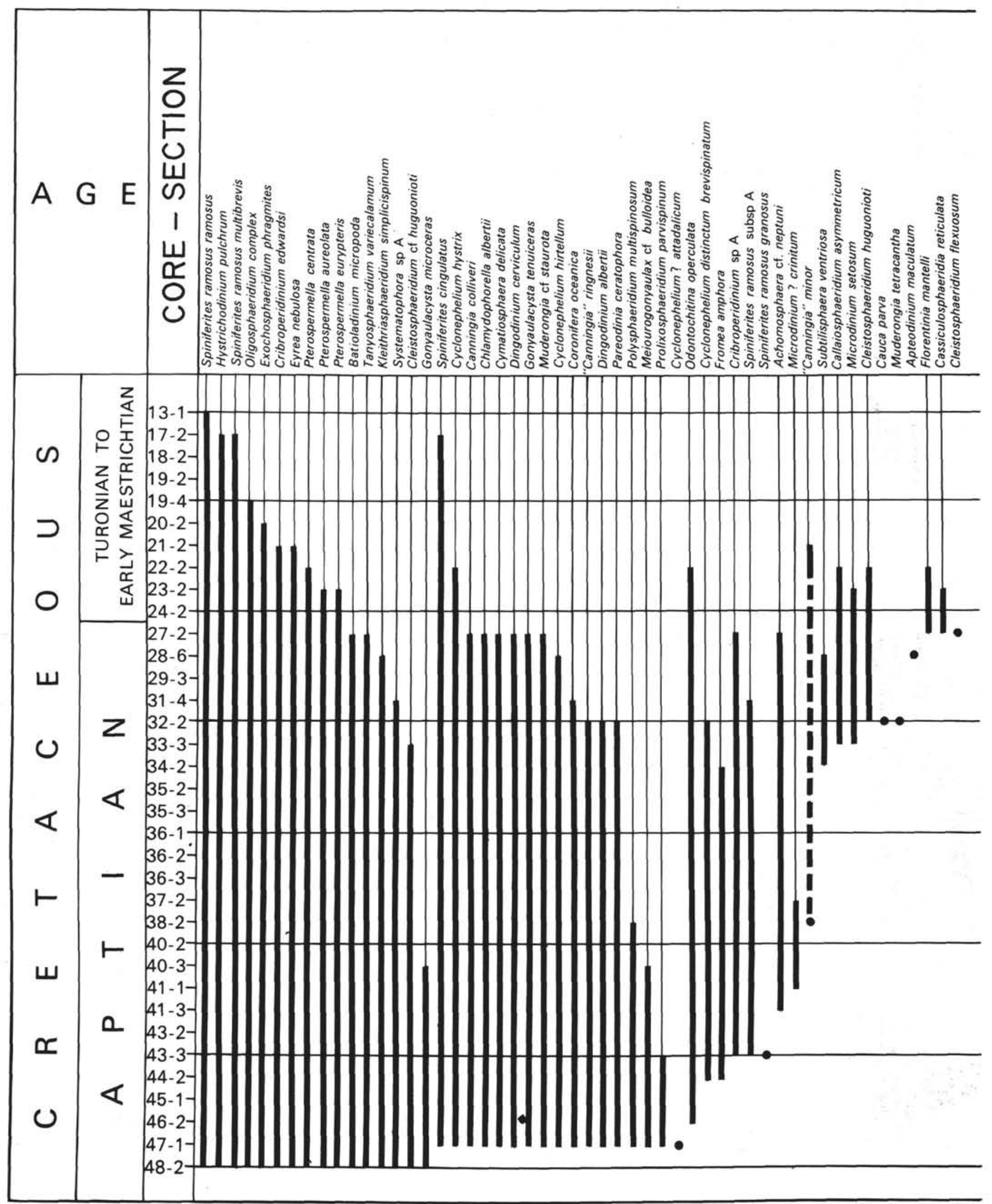

Figure 3. Range chart of marine palynomorphs of Cretaceous age from Site 361. 


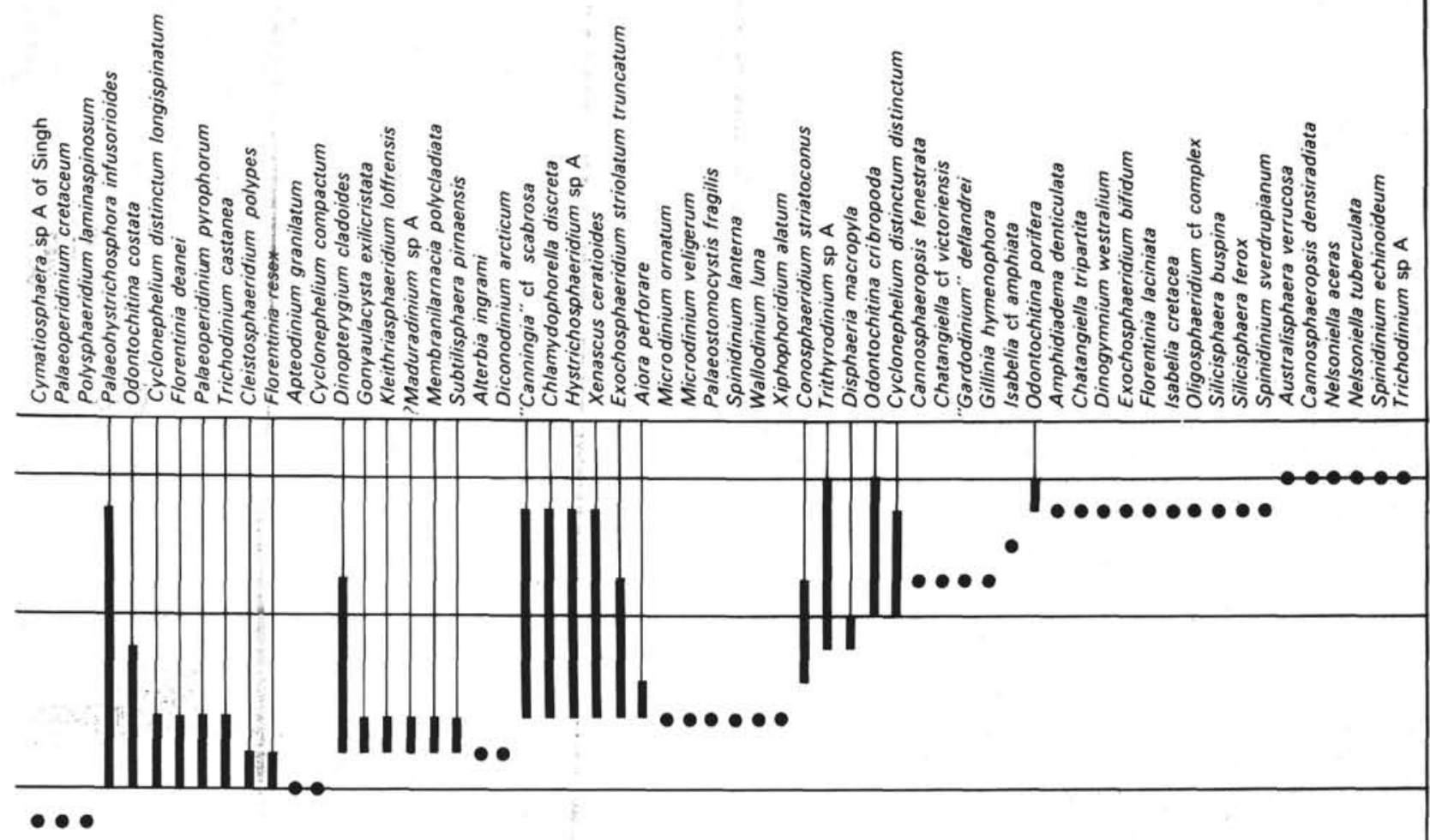

Figure 3. (Continued). 
confirm this when they indicate that Sections 25-3, 26$3,-4,-5$, and -6 are barren. Dinocyst assemblages of Albo-Cenomanian age are well known from Europe and Australia and many distinctive species, such as Litosphaeridium siphoniphorum (Cookson and Eisenack, 1958), Hystrichosphaeridium arundum Eisenack and Cookson, 1960, and genera, such Ovoidinium Davey, 1970, and Carpodinium Cookson and Eisenack, 1962b, are typically present. However, none of these forms were found at Site 361 which suggests that the Albo-Cenomanian is either absent or represented in the paleontologically barren Cores 26 and 25 .

\section{Cores 24 to 21: Turonian,}

Cores 20 to 13: Senonian to Maestrichtian

Many of the dinocyst species present in these cores are known to occur both in Europe and Australia but a few species have been previously only recorded from Australia. As in the Early Cretaceous, dating was effected principally by comparisons with European assemblages. A detailed stratigraphic study, by the author and Dr. J.-P. Verdier, of the late Albian to ?Santonian in the Loffre borehole, northern France, is in press, and several of the datings originate from this work. Even so, dating of the Site 361 Late Cretaceous is extremely tentative.

The following stratigraphically useful forms were recorded; Florentinia resex Davey and Verdier (1976) occurs in Cores 24 and 23, and in the Loffre borehole is restricted to the early Turonian. Subtilisphaera pirnaensis (Alberti, 1959), in Cores 23 and 22, is known to have principally an early to middle Turonian range in Europe, and Chlamydophorella huguonioti (Cores 23 and 22) ranges to the top of the Turonian. Core 21 does not contain any age-diagnostic European species although Conosphaeridium striatoconus (Deflandre and Cookson, 1955), previously found only in Australia, is considered to have a stratigraphic base in the Turonian. Core 20 does contain Hystrichisphaeridium sp. A., which has a basal occurrence in the Coniacian of Loffre, and Disphaeria macropyla Cookson and Eisenack, 1960a, an Australian form, reported to be principally of Coniacian age. A form similar to $D$. macropyla occurs in the late Coniacian -? Santonian of Loffre. Hence, on the evidence available, the TuronianConiacian boundary is tentatively placed between Samples 21-2, 131-133 cm and 20-2, 144-146 cm.

The comparison of assemblages from Cores 20 to 13 with European assemblages is not very meaningful and only a Senonian to early Maestrichtian age can be given. Many of the species present are restricted to and characteristic of the Australian Late Cretaceous and comparisons can easily be made with some of the described sequences. The most comparable sequence of assemblages was described by Cookson and Eisenack (1960a) from the Turonian to ?Campanian of Wapet's Rough Range South No. 1 bore, Carnarvon Basin, Western Australia. This publication, and all the many others these authors have published on Australian dinocysts, is basically a taxonomic study and it is impossible to construct a comprehensive distribution or range chart for the species present. Data from Australia, particularly Western Australia, indicate that Cores 20 to 13 are of Coniacian to Campanian age.

The genus Odontochitina Deflandre, 1935, represented by $O$. operculata (O. Wetzel, 1933a) ranges into the early Maestrichtian of Europe (Wilson, 1971) and suggests that Core 13, although containing a different species of $^{\circ}$ this genus (O. porifera Cookson, 1956), could be as young as early Maestrichtian. It is interesting to note that the characteristic deflandroid species of Senonian-Maestrichtian age described from Senegal by Jain and Millipied (1973), from Gabon by Malloy (1972) and from Ghana by Davey (in press) were not found at Site 361 .

\section{Paleoecological Considerations}

McLachlan and Pieterse (this volume) discuss the various organic components making up the Cretaceous palynologic residues. Of particular interest from a paleoecological standpoint is their fig. 2 which indicates the proportions of the various constituents. The following discussion reappraises the palynologic data available pertaining to the conditions of deposition and type of water mass present during Cretaceous times from a slightly different point of view.

\section{Aptian (Cores 48 to 27)}

The Aptian samples typically yield dinocyst assemblages which are relatively rich in species but poor in numerical abundance. The majority of these species also occur in France and Australia. Hence it must be concluded that at least the photic zone above the site of deposition, inhabited by the motile dinoflagellates, was of near normal salinity and, in addition, that there was free oceanic connection between northwest Europe, Site 361, and Australia. Water temperatures were also probably rather similar in these regions.

The organic residues of the Aptian are unusual and are characterized by an abundance of sapropelic or amorphous organic matter (AOM of Davey and Rogers, 1975) or MOC of McLachlan and Pieterse (this volume) and also by an unusual abundance of nonspinose acritarchs belonging to the genera Pterospermella Eisenack, 1972, Cymatiosphaera O. Wetzel, 1933b, and Eyrea Cookson and Eisenack, 1971. The AOM appears to be of marine origin in many of the regions where it has been recorded, e.g. the Late Jurassic of England, and in the Recent sediments offshore from South West Africa (Davey and Rogers, 1975 ) where it is associated with high marine phytoplankton productivity resulting from upwelling. However, in some AOM rich sediments, sporomorphs predominate over dinocysts. In this situation it is quite plausible to suggest that the AOM is associated with the sporomorphs and is of terrestrial origin.

The above acritarchs are a facies controlled element and have only previously been recorded together from Core 20 of the Eyre No. 1 bore, Eucla Basin, Western Australia (Cookson and Eisenack, 1971). The sediment here was described as a dark gray mudstone. In other parts of the world these non-spinose acritarchs, particularly Pterospermella and Cymatiosphaera. 
appear to be consistently associated with organic-rich sediments in the Mesozoic, e.g., in the mid-Cretaceous of central Canada (Davey, 1970; Singh, 1971), the Kimmeridgian of southern England, and the Kimmeridgian-Portlandian of the northern North Sea Basin. These forms do not occur in the Aptian of northwest Europe. The reason for this association is not known, but a correlation with large run-off from the landmass and basins with a somewhat restricted bottom circulation appeared to be indicated.

Sporomorphs are abundant in the Aptian and greatly outnumber the marine palynomorphs (see McLachlan and Pieterse, this volume). This palynomorph distribution is unusual in marine sediments and, together with the abundance of terrestrially derived plant material, indicates that there was a copious run-off from the neighboring landmasses which reached the site of deposition; it also suggests that the AOM is terrestrially derived. As the dinocyst assemblage is relatively rich, it is perhaps easiest to envisage bottom currents bringing this terrestrial debris to the site of deposition.

A final detail is that the chitinous linings of foraminifers (termed microforaminifers) are relatively common in most of the Aptian samples. At one time these would have been considered to be the remains of benthic foraminifers, but now, and particularly in the present situation, it appears more likely that they are derived from planktonic foraminifers which could represent early planktonic stages of benthic foraminifers. Anaerobic conditions undoubtedly prevailed beneath the water-sediment interface.

\section{Turonian to Early Maestrichtian (Cores 28 to 13)}

The amount of AOM in the sediment gradually decreases from Core 25 to disappear entirely by Core 21 . Core 22 contains the youngest stratigraphic appearance of Pterospermella, and Eyrea last occurs in Core 21; these distributions again suggest a strong link between these acritarchs and the AOM content of the sediment. The proportion of dinocysts to sporomorphs is considerably greater now than in the Aptian (see McLachlan and Pieterse, this volume), although marked fluctuations do occur, and indicate that normal marine conditions prevailed; the neighboring landmasses now had less influence at the site of deposition. In the Turonian many of the observed dinocysts are found also in France, England and Australia; however, in the Senonian considerably fewer of the species are common both to northwest Europe and to Site 361, whereas many distinctive species, only previously described from Australia, are now common. It would appear that either changes in oceanic currents or in climatic belts cut off the water mass off southwestern Africa during the Senonian from direct contact with Europe but did retain the direct link with Australia.

\section{SYSTEMATIC DESCRIPTIONS}

This section is divided into two parts. The first part lists, in alphabetical order, the marine palynomorph species encountered during this study which require no special remarks; illustrated specimens are indicated. The second part deals with additional species which require certain amplifying remarks because of their morphology or classification.

\section{Marine Palynomorph Species}

Achomosphaera cf. neptuni (Eisenack, 1958) Davey and Williams, 1966a, in Davey and Verdier, 1974 (Plate 1, Figure 1).

Alterbia ingrami (Cookson and Eisenack, 1970) Lentin and Williams, 1975b (Plate 7, Figures 1, 7).

Amphidiadema denticulata Cookson and Eisenack, 1960a.

Apteodinium granulatum Eisenack, 1958.

A. maculatum Eisenack and Cookson, 1960 (Plate 1, Figures 5, 6).

Batioladinium micropoda (Eisenack and Cookson, 1960) Brideaux, 1975 (Plate 1, Figure 4).

Callaiosphaeridium asymmetricum (Deflandre and Courteville, 1939) Davey and Williams, 1966b.

Canningia colliveri Cookson and Eisenack, 1960b (Plate 1, Figure 10). "C." minor Cookson and Hughes, 1964.

"C." ringesii Manum and Cookson, 1964 (Plate 1, Figures 9, 13, 14).

"C." cf. scabrosa Cookson and Eisenack, 1970a (Plate 1, Figures 7, 8; Plate 3, Figure 3).

Cannosphaeropsis densiradiata Cookson and Eisenack, 1962b (Plate 1, Figure 12).

Cassiculosphaeridia reticulata Davey 1969a (Plate 1, Figure 15).

Cauca parva (Alberti, 1961) Davey and Verdier, 1971.

Chatangiella tripartita (Cookson and Eisenack, 1960a) Lentin and Williams, 1975b (Plate 7, Figures 3-6).

C. cf. victoriensis (Cookson and Manum, 1964) Lentin and Williams, 1975b (Plate 7, Figures 8, 9).

Chlamydophorella albertii (Neale and Sarjeant, 1962) Davey comb. nov. (Plate 2, Figure 8).

C. discreta Clarke and Verdier, 1967 (Plate 1, Figure 16).

C. cf. huguonioti (Valensi, 1955a) comb. nov. (Plate 2, Figure 12).

Cleistosphaeridium flexuosum Davey et al., 1966 (Plate 2, Figure 13).

C. polypes (Cookson and Eisenack, 1962b) Davey, 1969a (Plate 2, Figure 11).

Coronifera oceanica Cookson and Eisenack, 1958.

Cribroperidinium edwardsi (Cookson and Eisenack, 1958) Davey 1969a (Plate 2, Figures 14, 15; Plate 4, Figures 8, 9).

Cyclonephelium ?attadalicum Cookson and Eisenack, 1962b (Plate 3, Figures 1, 2).

C. compactum Deflandre and Cookson, 1955 (Plate 3, Figures 5, 6).

Cymatiosphaera delicata Cookson and Eisenack, 1971 (Plate 9, Figure 9).

Cymatiosphaera sp. A of Singh, 1971.

Diconodinium arcticum Manum and Cookson, 1964.

Dingodinium albertii Sarjeant, 1966c.

D. cerviculum Cookson and Eisenack, 1958 (Plate 4, Figure 1).

Dinogymnium westralium (Cookson and Eisenack, 1958) Evitt et al., 1967.

Dinopterygium cladiodes Deflandre, 1935.

Eyrea nebulosa Cookson and Eisenack, 1971 (Plate 9, Figure 11).

Exochosphaeridium bifidum (Clarke and Verdier, 1967) Clarke et al., 1968.

E. phragmites Davey et al., 1966 (Plate 5, Figure 2).

E. striolatum (Deflandre, 1937b) subsp. truncatum Davey, 1969a.

Florentinia deanei (Davey and Williams, 1966b) Davey and Verdier, 1973.

F. laciniata Davey and Verdier, 1973.

F. mantelli (Davey and Williams, 1966b) Davey and Verdier, 1973.

F. resex Davey and Verdier (1976).

Fromea amphora Cookson and Eisenack, 1958.

"Gardodinium" deflandrei Clarke and Verdier, 1967.

Gillinia hymenophora Cookson and Eisenack, 1960a.

Gonyaulacysta exilicristata Davey, 1969a (Plate 4, Figures 4, 7).

G. microceras (Eisenack, 1958) Clarke and Verdier, 1967 (Plate 4, Figure 3).

G. tenuiceras (Eisenack, 1958) Sarjeant, 1969 (Plate 4, Figures 5, 6).

Hystrichodinium pulchrum Deflandre, 1935 (Plate 5, Figure 1).

Isabelia cf. ?amphiata (McIntyre, 1975) Lentin and Williams, 1975b (Plate 7, Figure 2).

I. cretacea (Cookson, 1956) Lentin and Williams, 1975b.

Kleithriasphaeridium loffrensis Davey and Verdier (1976).

K. simplicispinum (Davey and Williams, 1966b) Davey, 1974 (Plate 5, Figure 3)

Meiourogonyaulax cf. bulloidea (Cookson and Eisenack, 1960b) Sarjeant, 1969 (Plate 5, Figures 11, 12).

Membranilarnacia polycladiata Cookson and Eisenack in Eisenack, 1963a (Plate 5, Figures 8, 9).

Microdinium ?crinitum Davey, 1969a. 


\section{R. J. DAVEY}

M. ornatum Cookson and Eisenack, 1960a.

M. setosum Sarjeant, 1966b.

M. veligerum (Deflandre, 1937b) Davey, 1969a.

Muderongia cf. staurota Sarjeant, 1966c (Plate 6, Figure 6).

M. tetracantha (Gocht, 1957) Alberti, 1961 (Plate 6, Figure 3).

Nelsoniella aceras Cookson and Eisenack, 1960a (Plate 8, Plate 10).

N. tuberculata Cookson and Eisenack, 1960a.

Odontochitina costata Alberti, 1961 (Plate 6, Figure 4).

O. cribropoda Deflandre and Cookson, 1955 (Plate 6, Figure 2).

O. operculata (O. Wetzel, 1933a) Deflandre and Cookson, 1955.

O. porifera Cookson, 1956 (Plate 6, Figures 1, 7).

Oligosphaeridium complex (White, 1842) Davey and Williams, 1966b (Plate 5, Figure 13).

O. cf. complex (White, 1842) Davey and Williams, 1966b (Plate 5, Figure 10).

Palaeohystrichophora infusorioides Deflandre, 1935.

Palaeoperidinium cretaceum Pocock, 1962, ex Davey, 1970 (Plate 8, Figure 6).

P. pyrophorum (Ehrenberg, 1838) Deflandre, 1935 (Plate 8, Figure 5).

Palaeostomocystis fragilis Cookson and Eisenack, 1962b.

Pareodinia ceratophora Deflandre, 1947c (Plate 5, Figure 7; Plate 8, Figure 12).

Polysphaeridium laminaspinosum Davey and Williams, 1966b.

P. multispinosum Davey, 1974.

Prolixosphaeridium parvispinum (Deflandre, 1937b) Davey et al., 1969.

Pterospermella aureolata (Cookson and Eisenack, 1958) Eisenack, 1972

P. centrata (Cookson and Eisenack, 1971) Eisenack and Cramer, 1973 (Plate 9, Figures 5-7).

P. eurypteris (Cookson and Eisenack, 1958) Eisenack and Cramer, 1973.

Silicisphaera buspina Davey and Verdier (1976).

$S$. ferox (Deflandre, 1937b) Davey and Verdier (1976).

Spinidinium echinoideum (Cookson and Eisenack, 1960a).

S. lanterna Cookson and Eisenack, 1970a (Plate 8, Figure 13).

S. sverdrupianum (Manum, 1963) Lentin and Williams, 1975b (Plate 9, Figures 12, 13).

Spiniferites cingulatus (O. Wetzel, 1933b) Sarjeant, 1970.

$S$. ramosus (Ehrenberg, 1838) subsp. granosus Davey and Williams, 1966a.

S. ramosus subsp. ramosus (Ehrenberg, 1838) Sarjeant, 1970.

Subtilisphaera pirnaensis (Alberti, 1959b) Jain and Millepied, 1973 (Plate 8, Figure 7).

S. ventricosa (Alberti, 1959b) Jain and Millepied, 1973 (Plate 8, Figures 1-4, 8, 9).

Tanyosphaeridium variecalamum Davey and Williams, 1966b.

Trichodinium castanea (Deflandre, 1935) Clarke and Verdier, 1967 (Plate 9, Figure 2).

Wallodinium luna (Cookson and Eisenack, 1960a) Lentin and Williams, 1973.

Xenascus ceratioides (Deflandre, 1937b) Lentin and Williams, 1973 (Plate 6, Figure 5).

Xiphophoridium alatum Sarjeant, 1966b.

\section{Class DINOPHYCEAE Fritsch, 1929}

\section{Order PERIDINIALES Haeckel, 1894}

Genus AIORA Cookson and Eisenack, 1960a, emend.

Type species: Aiora perforare nom. nov., ?Turonian-Senonian, Australia.

Emended diagnosis: The cyst consists of a dorso-ventrally flattened shell, subcircular in outline, from which radiate a low number of processes in the plane of flattening at or near the lateral margins. These processes either branch complexly and link distally with the two adjacent processes or broaden into a surrounding fenestrate membrane, all in the plane of flattening; the outline of this outer structure is subcircular. The archeopyle is dorsal precingular formed by the loss of a single plate (type P).

Remarks: The diagnosis of this genus is emended to draw attention to the positioning of the processes and to the presence of a dorsal precingular archeopyle.
Cookson and Eisenack erected the genus Aiora in 1960 and made Cannosphaeropsis fenestrata Deflandre and Cookson, 1955, the type species. However, it is considered that Cookson and Eisenack incorrectly attributed specimens that they found during their 1960 study to the previously described species $C$. fenestrata. The illustration of the holotype of the latter species (Deflandre and Cookson, 1955, pl. 3, fig. 2) distinctly shows that numerous processes radiate from the entire shell surface and are not restricted to one plane as in Aiora. Cookson and Eisenack's specimens are distinctive and warrant a separate genus; this they descirbed as Aiora, basing it on the Rough Range specimens which are below transferred from Cannosphaeropsis fenestrata to A. perforare nom. nov. which thus becomes the type species of the genus.

\section{Aiora perforare nom. nov.}

(Plate 1, Figures 2, 3)

1960 Aiora fenestrata (Deflandre and Cookson, 1955) Cookson and Eisenack, p. 9, pl. 2, fig. 17, 18. NON Cannosphaeropsis fenestrata Deflandre and Cookson, 1955, p. 283, pl. 3, fig. 2.

Derivation of name: Latin, perforare, perforate-with reference to the distal nature of the processes.

Diagnosis: A species of Aiora possessing a smooth, thin-walled shell of subcircular outline from which arise approximately five flat, equally spaced processes or process groups. These may subdivide proximally and/or medially to give rise to two or more branches diverging in the plane of flattening, and distally in a complex manner to form a fenestrate membrane. The fenestrations are subcircular to rounded-polygonal in outline and tend to become smaller distally. The membrane links adjacent processes and forms a continuously circular network around the shell. The outer extremity of the membrane is smooth and tends to be slightly recurved.

Holotype: Nat. Mus. Vic. No. P17808. Illustrated as the hypotype of Aiora fenestrata, Cookson and Eisenack, 1960a, pl. 2, fig. 17.

Dimensions: From Cookson and Eisenack, 1960: holotype (measured from illustration pl. 2, fig. 17), shell diameter $50 \times 65 \mu \mathrm{m}$, overall diameter $115 \times 150 \mu \mathrm{m}$; range, shell diameter 50-80 $\mu \mathrm{m}$, overall diameter 120-160 $\mu \mathrm{m}$. Figured specimen, Plate 1, Figures 2, 3, shell diameter $51 \times 59 \mu$, overall diameter $120 \times 130 \mu \mathrm{m}$.

Description: The exact nature of the processes is difficult to determine but they appear to be single layered, flattened, or membranous structures. Five of these processes are present in the illustrated specimen. Here two appear to arise on opposite sides of the shell from high up on the precingular plates; one is cingular arising from the left margin, one is postcingular arising from the right margin and one is antapical. An alternative way of describing this cyst would be to consider its basic morphology to be comparable to that of a Pterospermella species possessing a fenestrate periphragm wing. Approximately five large proximal perforations should then be evisaged with an increase in number, but decrease in size of the fenestration as the outer limit of the wing is approached. No direct relationship between Aiora and Pterospermella, however, is in any way implied here.

\section{Genus AUSTRALISPHAERA gen. nov.}

Type species: Australisphaera verrucosa sp. nov., CampanianMaestrichtian, offshore South Africa, DSDP Leg 40, Site 361.

Derivation of name: Latin, australis, southern-with reference to its southerly occurrence in the South Atlantic.

Diagnosis: The cyst is dorso-ventrally flattened and has a subpolygonal outline; the hypotract is slightly asymmetric. A single antapical and two lateral features, developed as a relatively high ornament or low to high horns, are present. The ornament is low and high spines or processes are absent. The archeopyle is apical with a slightly to moderately zig-zag margin; the sulcal notch is offset to the left of the mid-line.

Remarks: The combination of slight asymmetry and lack of spinose ornament distinguishes Australisphaera from previously described genera; the horns, when developed, are quite unique. Australiasphaera appears to possess the basic ceratioid features, as outlined by Wall and Evitt (1975), but does not appear to be closely related to any of the Cretaceous ceratioid genera. Unfortunately, as yet, no complete specimens or detached operculae of $A$. verrucosa have been identified, so the form of the apical region remains unknown. 


\section{Australisphaera verrucosa sp. nov.}

(Plate 2, Figures 1-5)

Diagnosis: A specimen of Australisphaera possessing a wall of moderate thickness which has a closely spaced surface ornament of low verrucae. The verrucae are larger in the lateral and antapical regions when they may be the only indication of these features. The horns, when present, grade from low bulges of the cyst wall to relatively long horns; the antapical horn arises from the ventral surface. The operculum is typically detached.

Holotype: MPK 1031, DSDP Leg 40, Site 361, Sample 13-1, $123-$ $125 \mathrm{~cm}$. Campanian-Maestrichtian, offshore South Africa.

Paratype: MPK 1032, DSDP Leg 40, Site 361, Sample 13-1, 123$125 \mathrm{~cm}$. Campanian-Maestrichtian, offshore South Africa.

Dimensions:

$\begin{array}{lccc} & \text { Holotype } & \text { Paratype } & \text { Range } \\ \text { Overall width } & 110 \mu \mathrm{m} & 137 \mu \mathrm{m} & 98(113) 137 \mu \mathrm{m} \\ \text { Overall width (operculum } & 89 \mu \mathrm{m} & 94 \mu \mathrm{m} & 70(85) 98 \mu \mathrm{m}\end{array}$

verall width

detached)

Paratype: Approximate length of lateral horns 30 and $45 \mu \mathrm{m}$; length of antapical horn $30 \mu \mathrm{m}$.

Description: The wall is of 1 to $1.5 \mu \mathrm{m}$ thick and the low tubercles, which completely cover the surface, are usually less than $0.5 \mu \mathrm{m}$ high. The large tubercles, mentioned in the diagnosis, and restricted to the lateral and antapical regions measure up to $3 \mu \mathrm{m}$ in height and are particularly noticeable at the ends of the horns. The lateral horns tend to be of unequal length and may be notched. The sulcal notch is not an obvious feature of the archeopyle margin and definite splitting of the cyst wall along the precingular plate boundaries is minimal. Only rarely can any signs of a pre- and postcingular tabulation be discerned.

Genus CANNOSPHAEROPSIS O. Wetzel, 1933b, emend. Williams and Downie, 1966c

\section{Cannosphaeropsis fenestrata Deflandre and Cookson, 1955} (Plate 1, Figure 11)

1955 Cannosphaeropsis fenestrata Deflandre and Cookson, p. 283, pl. 3 , fig. 2 .

Remarks: The retention of the type of this species in the genus Cannosphaeropsis has been discussed under the genus Aiora.

Genus CHLAMYDOPHORELLA Cookson and Eisenack, 1958

1961 Gardodinium Alberti, p. 18.

Remarks: There appears to be no justification for keeping the morphologically identical genera Chlamydophorella and Gardodinium separate and hence their synonymization is here proposed. The reason that this has not been done before is because of the uncertainty of the archeopyle type of Gardodinium. G. deflandrei Clarke and Verdier (1967) has an obvious precingular archeopyle and it was erroneously assumed that other species, including the type species, of this genus had a similar type of archeopyle. However, the type species of Gardodinium, G. trabeculosum Gocht, 1959, was shown by Davey (1974) to have an apical archeopyle and to be morphologically very similar to Chlamydophorella nyei Cookson and Eisenack, 1958, the type species of its genus.

Chlamydophorella is characterized by a subsphaerical to subpolygonal inner body which bears numerous short processes. The latter distally support a fine membrane which more or less completely surrounds the thicker walled inner body. However, the outer membrane being fine often suffers breakage and this appears to occur in some species more than others; the processes then are isolated and distally are membranous. It is possible that sometimes these isolated processes were never linked distally by a membrane. Signs of a tabulation may be present and apical horns may be developed both on the inner body and by the outer membrane. The archeopyle is apical. Perhaps the most characteristic feature of the genus, however, is considered to be the short, distally bifurcating processes. When fine, the processes appear to be solid but when stouter they are obviously hollow with the lumen partly restricted by septa (see Chlamydophorella huguonioti as Cleistosphaeridium ancoriferum in Cookson and Eisenack, 1968. p. 120, and in Davey, 1969a, p. 155).

The stratigraphic range of Chlamydophorella, including Gardodinium, is Late Jurassic to Late Cretaceous with a peak abundance in the Early and Middle Cretaceous. The Jurassic genus Stephanelytron Sarjeant, 1961, is probably an early member of this lineage.

Chlamydophorella huguonioti (Valensi, 1955a) comb. nov. (Plate 2, Figures 9, 10)

1955a Hystrichosphaeridium huguonioti Valensi, p. 38, fig. 2A. 1960a H. ancoriferum Cookson and Eisenack, p. 8, pl. 2, fig. 11. 1969a Cleistosphaeridium huguonioti (Valensi) Davey, p. 155, pl. 7, fig. 10.

Remarks: The present well-preserved specimens are identical to those described from Australia and Europe in several publications. The processes are of the stouter type typical of the genus Chlamydophorella and primarily for this reason this species has been transferred to the latter genus. There has been considerable discussion as to whether or not a surrounding membrane exists or that isolated processes terminating with a thin, transparent membrane are only present. Both extremes appear to exist and can be justifiably accommodated within a single species. There is no doubt that the present specimens do possess a completely surrounding outer membrane in the majority of cases. Occasionally this can be seen to be broken and discontinuous, and then the processes become isolated and have membranous distal extremities. Hence the presence or absence of an outer membrane is probably related to specimen preservation and, in addition, may be difficult to positively identify even when it is present.

\section{OTHER SPECIES}

The following species, formerly placed in Gardodinium, are here transferred to Chlamydophorella. The taxonomic position of Gardodinium deflandrei Clarke and Verdier will be discussed in a forthcoming paper by Dr. J.-P. Verdier and the author.

Chlamydophorella albertii (Neale and Sarjeant) Davey, comb. nov. = Gardodinium albertii Neale and Sarjeant, 1962, p. 445, pl. 19, fig. 6. Hauterivian, England.

Chlamydophorella elongata (Singh) Davey, comb. nov. = Gardodinium elongatum Singh, 1971 , p. 381 , pl. 68, fig. 3, 4. Albian, Canada.

Chlamydophorella ordinale (Davey) Davey, comb. nov. = Gardodinium ordinale Davey, 1974, p. 51, pl. 3, fig. 5, 6. Barremian, England.

Chlamydophorella pyriformis (Vozzhennikova) Davey, comb. nov. = Gardodinium pyriformis Vozzhennikova, 1967, p. 179, pl. 100, fig. 1, 4. Barremian, U.S.S.R.

Chlamydophorella trabeculosa (Gocht) Davey, comb. nov. = Scriniodinium trabeculosum Gocht, 1959, p. 62, pl. 4, fig. 5 . Hauterivian, Germany.

\section{Genus CONOSPHAERIDIUM Cookson and Eisenack, 1969}

\section{Conosphaeridium striatoconus (Deflandre and Cookson, 1955) Cookson and Eisenack, 1969}

(Plate 2, Figures 6, 7)

Remarks: Although this is a relatively common species in the younger Cretaceous samples from Site 361 , the specimens are often distorted. The shape of the archeopyle is polygonal, as noted by Cookson and Eisenack (1969), and only rarely approaches the classical precingular plate shape; detached operculae (Plate 2, Figure 7) are of similar form and bear a single process. Although not conclusive, evidence does strongly suggest that the archeopyle is formed by the loss of a single precingular plate.

Genus CRIBROPERIDINIUM Neale and Sarjeant, 1962, emend. Davey, 1969a

\section{Cribroperidinium sp. A.}

(Plate 4, Figure 2)

Description: A large species of Cribroperidinium having a rather thin, pitted wall and a weak tabulation defined mainly by low ridges. The latter sometimes develop low spines, especially along the apical horn, that are linked distally by trabeculae. The apical horn is strong and is of a subconical shape. 


\section{Genus CYCLONEPHELIUM Deflandre and Cookson, 1955,} emend. Williams and Downie, 1966c

Remarks: During this investigation some difficulty was experienced in allocating the rather variable group of dinocysts characterized by a spinose ornament and an angular apical archeopyle to described species. Variation is mainly in the shape of the antapex and the length, density, and distribution of the spines. As so many specimens over a considerable stratigraphic interval were available for study, a re-evaluation of this group is attempted below.

\section{Cyclonephelium distinctum subsp. distinctum Deflandre and Cookson, 1955 \\ (Plate 3, Figures 9, 12)}

Remarks: The holotype of this species was re-illustrated by Cookson and Eisenack in $1962 \mathrm{~b}$ (pl. 5, fig. 5), and this illustration clearly shows that practically all the dorsal and ventral surfaces are devoid of processes. Identical specimens occur at Site 361 and these are associated with the same dinocyst assemblage as occurs with the type material (in the Molecap Greensand, near Gingin, Western Australia) and are likewise of Senonian age. Cookson and Eisenack also attribute other specimens to $C$. distinctum (pl. 5, fig. 6-11) which are more densely spined, have smaller bald areas, and reportedly come from the Albo-Cenomanian of Western Australia. This second morphological group can easily be distinguished from the type material of $C$. distinctum distinctum and also occurs in the older strata at Site 361; below these are attributed to a new subspecies of $C$. distinctum.

\section{Cyclonephelium distinctum subsp. longispinatum subsp. nov.} (Plate 3, Figures 4, 7, 8)

Diagnosis: A subspecies of $C$. distinctum having a denser covering of long spines which extend well on to the dorsal and ventral surfaces leaving only small areas devoid of processes.

Type: MPK 1039, DSDP Leg 40, Site 361, Sample 24-2, $9698 \mathrm{~cm}$. Turonian, offshore South Africa.

Dimensions: Type: length of shell (including operculum) $65 \mu \mathrm{m}$, width $60 \mu \mathrm{m}$, length of processes 8-14 $\mu \mathrm{m}$. Range: length of shell (operculum detached) $48-53 \mu \mathrm{m}$, width $54-60 \mu \mathrm{m}$, length of processes up to $15 \mu \mathrm{m}$.

\section{Cyclonephelium distinctum subsp. brevispinatum Millioud, 1969} (Plate 3, Figures 13-15)

Remarks: To this subspecies were attributed specimens possessing very short spines and a rounded to only slightly indented antapex. Similar specimens possessing a markedly indented antapex are placed in Canningia colliveri Cookson and Eisenack, $1960 \mathrm{~b}$.

\section{Cyclonephelium hirtellum (Alberti) comb. nov.}

1961 Circulodinium hirtellum Alberti, p. 28, pl. 4, fig. 20.

1969 Canningia hirtella (Alberti) Millioud, p. 425.

Remarks: The original diagnosis of this species clearly indicates that the spines (3-4 $\mu \mathrm{m}$ in length) are restricted to the lateral margins of the shell. This characteristic indicates that the affinities of $C$. hirtellum lie more with Cyclonephelium than Canningia where the ornament, when present, is extremely low and should cover all surfaces equally. C. hirtellum is also characterized by two rounded antapical horns.

\section{Cyclonephelium hystrix (Eisenack) comb. nov.}

(Plate 3, Figures 10, 11)

1958 Tenua hystrix Eisenack, p. 410, pl. 23, fig. 1-4.

Remarks: Eisenack's type material of this species possesses the characteristics which typify the genus Cyclonephelium-processes more or less restricted to a circumferential zone and an angular apical archeopyle-and it is therefore transferred to this genus. C. hystrix is characterized by numerous short, generally less than $10 \mu \mathrm{m}$, distally bifid processes and a rounded antapex.

The above transference effectively removes the type species from Tenua Eisenack, 1958. However, Tenua was originally defined as having an overall covering of short processes, and has an obvious apical archeopyle. Hence the type species, T. hystrix, possessing bald areas, never precisely complied with the generic diagnosis. Since its erection, Tenua has been widely used and has come to be regarded as being characteristic of the later Jurassic and all the species subsequently erected have been of this age. Only the type species is of Cretaceous age and this has fallen into disuse mainly because it does not comply with the generic diagnosis. It is hence here proposed to conserve the name Tenua, retaining Eisenack's original definition, and to erect $T$. rioulti Sarjeant as the new type species.

Genus TENUA Davey nom. cons. (non Tenua Eisenack, 1958)

Type species: Tenua rioulti Sarjeant, 1968; p. 231, pl. 1, fig. 12, 22; pl. 2, fig. 1, 2, 4. Late Callovian, France.

\section{Genus DINGODINIUM Cookson and Eisenack, 1958}

Remarks: Although D. albertii Sarjeant, $1966 \mathrm{c}$ and D. cerviculum Cookson and Eisenack, 1958, were synonymized by Haskell in 1969 , workers in various parts of the world continued to use either one or the other specific name; the two species are also still listed separately by Lentin and Williams (1973) suggesting that this synonymization was not accepted. The Europeans have tended to use $D$. albertii for their specimens and the Australians and Canadians use D. cerviculum. The difference between the two species is one of size rather than morphology: $D$. albertii, overall length of type material $50-66 \mu \mathrm{m} ; D$. cerviculum, overall length of type material $81-109 \mu \mathrm{m}$. This separation on size appears to be valid because during the present study the specimens of Dingodinium could be immediately assigned either to a group of small specimens (D. albertii) having an overall length of 56 (60) $63 \mu \mathrm{m}$ or to a group of larger specimens with an overall length of $75(88) 100 \mu \mathrm{m}$.

\section{Genus DISPHAERIA Cookson and Eisenack, 1960a}

\section{Disphaeria macropyla Cookson and Eisenack, 1960a} (Plate 4, Figures 10,11)

Remarks: This species is composed of a small sack enclosed within a larger one, the two being in contact only on the supposed dorsal surface. On the single well-preserved specimen encountered there does appear to be a small precingular ( $\left.3^{\prime \prime}\right)$ plate archeopyle as implied by Norvick (1973). The apex of the inner sack bears several tubercles and additional tubercles are present on the dorsal periphragm. A large circular opening is present on the ventral surface. Very similar forms occur in the French Late Cretaceous and here the archeopyle is definitely precingular $3^{\prime \prime}$. At the moment I do not consider that Thalassiphora Eisenack and Gocht, 1960, should be made a junior synonym of Disphaeria because of marked difference in wall structure. An interesting parallelism with regard to the ventral opening is its presence in ? Spiniferites sp. of Wilson, 1971, from the Maestrichtian, and in Spiniferites sp. A. of de Coninck, 1975, of Danian-middle Paleocene age.

\section{Genus EXOCHOSPHAERIDIUM Davey et al., 1966}

Remarks: Because of overall morphology and, in particular, the wall structure and precingular $\left(3^{\prime \prime}\right)$ archeopyle, the following species is here transferred to Exochosphaeridium.

Exochosphaeridium truncigerum (Deflandre) Davey, comb. nov. = Hystrichosphaeridium truncigerum Deflandre, 1937b, p. 71, pl. 13, fig. 6, 7. Late Cretaceous, France. (Illustrated herein on Plate 4, Figures 12, 13).

\section{Genus HYSTRICHOSPHAERIDIUM Deflandre, 1937b, emend. Davey and Williams, 1966b}

\section{Hystrichosphaeridium sp. A.} (Plate 5, Figure 4)

Remarks: A dinocyst species which possesses very fibrous, parallel-sided processes which widen distally to terminate with a recurved margin. The shell surface is fibrous and usually strongly reticulate. The precise position of the archeopyle has not been determined with certainty.

\section{Genus MADURADINIUM Cookson and Eisenack, 1970a}

\section{?Maduradinium sp. A.}

(Plate 5, Figures 5, 6)

Remarks: ?Maduradinium sp. A. is identical to specimens encountered in the Turonian-Coniacian of France. These specimens have, in common with M. pentagonum Cookson and Eisenack (1970a) 
from Australia, a thin wall, the characteristic patches of granulation and irregular tubercles, and are of polygonal shape. However, apical and antapical horns and an intercalary archeopyle are lacking in the European and South African specimens. Here the granulation is concentrated at the antapex, the cingulum and, to a lesser extent, along the weak tabulation. Archeopyle breakage is in the apical region and pronounced sutural splitting occurs between the precingular plates. It is possible that the apical plates are lost but this has yet to be confirmed.

Genus SPINIFERITES Mantell, 1850, emend. Sarjeant, 1970

Spiniferites ramosus (Ehrenberg, 1838) subsp. A. (Plate 6, Figures 8, 9)

Remarks: This form is similar to $S$. ramosus multibrevis Davey and Williams, 1966a, but possesses a thick, intraperforate wall with more numerous and finer sutural processes.

\section{Genus SYSTEMATOPHORA Klement, 1960}

\section{Systematophora sp. A.}

(Plate 9, Figures 1, 10)

Description: The processes of this species vary considerably from specimen to specimen and upon an individual. The cingular processes are of the bipartite type, typical of the genus, and each branch bifurcates distally. The post-, precingular, and antapical processes are more complex and arise from a circular or arcuate proximal ridge. They tend to be either flat and membranous and branch irregularly distally, or are composed of several branching processes which arise directly from the proximal ridge. The former type of process often gives the impression of being an aberrant tubular process that has lost part of its wall.

Genus TRICHODINIUM Eisenack and Cookson, 1960, emend. Clarke and Verdier, 1967

\section{cf. Trichodinium sp. A.} (Plate 9, Figure 3)

Description: This is a subsphaerical species composed of a thick, intraperforate wall. The numerous spines tend to be concentrated in the peritabular regions, leaving the sutural regions and the centers of the plates relatively free of processes. The spines are linked distally.

Genus TRITHYRODINIUM Drugg, 1967, emend. Lentin and Williams, 1975b

Trithyrodinium sp. A.

(Plate 9, Figures 14, 15)

Description: Several Senonian samples contained isolated endocysts with 3-plate intercalary endoarcheopyles. The walls of these endocysts are lightly to heavily granular. Such endocysts, having the intercalary plates cleanly detached rather than remaining partly joined to the endocysts, are typical of Trithyrodinium. However, since the pericyst was never observed, specific determination was not possible.

\section{REFERENCES}

(All references to dinocysts mentioned in the text but not listed below are to be found in Lentin and Williams, 1973, 1975a.)

Brideaux, W.W., 1975. Taxonomic note: redefinition of the genus Broomea and its relationship to Batioladinium gen. nov. (Cretaceous): Canadian J. Bot., v. 53, p. 1239-1243.
Burger, D., in preparation. Palynological studies in the Great Artesian Basin, Australia. Part 1: Lower Cretaceous, Surat Basin, Queensland.

Davey, R.J., in press. A dinoflagellate cyst assemblage from the Late Cretaceous of Ghana: Fifth African Coll. Micropaleontol., Proc.

Davey, R.J. and Rogers, J., 1975. Palynomorph distribution in Recent offshore sediments along two traverses off South West Africa: Marine Geol., v. 18, p. 213-225.

Davey, R.J. and Verdier, J-P., 1976. A review of certain nontabulate Cretaceous hystrichospheres: Rev. Palaeobotan. Palynol., v. 22, p. 307-335.

De Coninck, J., 1975. Organic-walled microfossils from the Upper Danian and Middle Paleocene of Southern Sweden: Geol. För. Stockh. Förh., v. 97, p. 326-337.

Dettmann, M.E., 1963. Upper Mesozoic microfloras from southeastern Australia: Roy. Soc. Victoria Proc., v. 77, p. 1-148.

Eisenack, A., 1972. Kritische Benerkung zur Gattung Pterospermopsis (Chlorophyta, Prasinophyceae): N. Jb. Geol. Paläont. Mh., p. 596-601.

Eisenack, A. and Cramer, F.H., 1973. Katalog der fossilen Dinoflagellaten, Hystrichosphären und verwandten Mikrofossilien. Band III: Acritarcha, 1. Teil: Stuttgart.

Fritsch, F.E., 1929. Evolutionary sequence and affinities among Protophyta: Biol. Rev., v. 4, p. 103-151.

Haeckel, E., 1894. Entwurf eines naturlichen Systems der Organismen auf Grund ihrer Stammegeschichte, Erster Theil. Systematische Phylogenie der Protisten und Pflanzen: Berlin (Georg Reimer).

Haskell, T.R., 1969. Dinoflagellate species Dingodinium cerviculum, Odontochitina operculata, and Muderongia tetracantha in Lower Cretaceous strata of the Great Artesian Basin, Australia: Roy. Soc. Queensland Proc., v. 81, p. $57-68$.

Lentin, J.K. and Williams, G.L., 1973. Fossil dinoflagellates: index to genera and species: Geol. Surv. Canada Pap. No. $73-42$, p. 1-176.

1975a. Fossil dinoflagellates: index to genera and species. Supplement 1: Canadian J. Bot., v. 53, p. $2147-$ 2157.

, 1975b. A monograph of fossil peridinoid dinoflagellate cysts: Bedford Inst. Oceanogr., Rept. Ser. 75-16, p. $1-237$.

McIntyre, D.J., 1975. Morphologic changes in Deflandrea from a Campanian section, District of Mackenzie, N.W.T., Canada: Geosci. and Man, v. 11, p. 61-76.

Morgan, R., 1975. Some Early Cretaceous organic-walled microplankton from the Great Australian Basin, Australia: J. Proc. Roy. Soc. N.S.W., v. 108, p. 157-167.

Verdier, J-P., 1975. Les kystes de dinoflagellés de la section de Wissant et leur distribution stratigraphique au Crétacé moyen; Rev. Micropaléontol., v. 17, p. 191-197.

Wall, D. and Evitt, W.R., 1975. A comparison of the modern genus Ceratium Schrank, 1793, with certain Cretaceous marine dinoflagellates: Micropaleontology, v. 21, p. 1444.

Wilson, G.J., 1971. Observations on European Late Cretaceous dinoflagellate cysts. In Farinacci, A. (Ed.), Second Plankt. Conf. Roma, Proc., 1970, Rome (Tecnoscienza), p. 1259-1275. 


\section{PLATE 1}

Figure $1 \quad$ Achomosphaera cf. neptuni (Eisenack). Slide CSA $1751 / 1$, MPK 1040. Shell $42 \times 42 \mu \mathrm{m}$, processes 8$13 \mu \mathrm{m}$.

Figures 2, 3 Aiora perforare nom. nov. Slide SOEKOR 4988(b).1, co-ordinates $8.8 / 74.2$. Overall diameter $124 \times 129 \mu \mathrm{m}$, inner sac diameter $51 \times 60 \mu \mathrm{m}$.

2. Ventral surface.

3. Dorsal surface.

Figure $4 \quad$ Batioladinium micropoda (Eisenack and Cookson). Slide SOEKOR 4998(b).1, co-ordinates 1.7/91.5. $56 \times 29 \mu \mathrm{m}$.

Figures 5,6 Apteodinium maculatum Eisenack and Cookson. Slide CSA 1736/1, MPK 1042. Overall diameter $95 \times 82 \mu \mathrm{m}$.

5. Ventral surface.

6. Dorsal surface.

Figures 7, 8 "Canningia" cf. scabrosa Cookson and Eisenack.

7. Slide CSA $1726 / 1$, MPK 1045. Overall diameter $60 \times 70 \mu \mathrm{m}$.

8. Slide CSA $1732 / 1$, MPK 1050. Overall diameter $69 \times 79 \mu \mathrm{m}$.

Figure $9 \quad$ "Canningia" ringnesii Manum and Cookson. Slide CSA 1736/1, MPK 1043. Overall diameter $41 \times$ $44 \mu \mathrm{m}$.

Figure 10 Canningia colliveri Cookson and Eisenack. Slide CSA $1758 / 3$, MPK 1059. Shell diameter $89 \times 74$ $\mu \mathrm{m}$, spines up to $1.5 \mu \mathrm{m}$.

Figure 11 Cannosphaeropsis fenestrata Deflandre and Cookson. Slide SOEKOR 4985(b).1, co-ordinates 17.5/97.2. Overall diameter $80 \times 63 \mu \mathrm{m}$.

Figure 12 Cannosphaeropsis densiradiata Cookson and Eisenack. Slide CSA 1725/2, MPK 1033. Overall diameter $68 \times 65 \mu \mathrm{m}$.

Figures 13,14 "Canningia" cf. ringnesii Manum and Cookson.

13. Slide SOEKOR 4993(b).1, co-ordinates $6.3 / 83.8$. Overall diameter $78 \times 65 \mu \mathrm{m}$.

14. Slide CSA 1755/1, MPK 1061. Overal! diameter $65 \times 64 \mu \mathrm{m}$.

Figure 15 Cassiculosphaeridia reticulata Davey. Slide CSA $1735 / 1$, MPK 1062. Shell diameter $49 \times 50 \mu \mathrm{m}$, crests up to $1.5 \mu \mathrm{m}$.

Figure 16 Chlamydophorella discreta Clarke and Verdier. Slide CSA 1726/1, MPK 1046. Overall diameter $36 \times 37 \mu \mathrm{m}$. 
PLATE 1
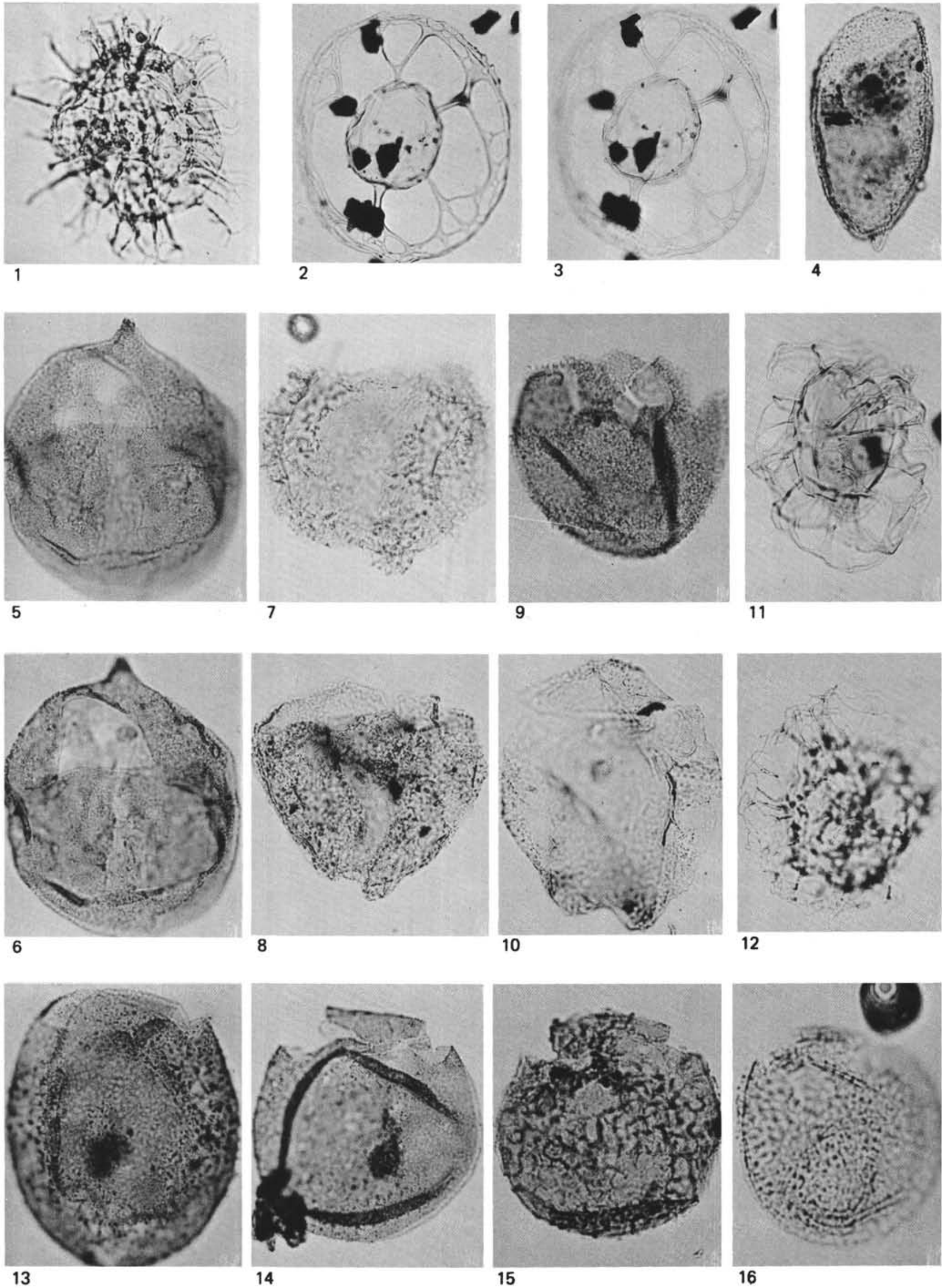


\section{PLATE 2}

Figures 1-5 Australisphaera verrucosa $\mathrm{sp}$. nov.

1. Holotype. Note that the antapical horn arises from the ventral surface rather than at the antapex.

2. Paratype.

3. Slide SOEKOR 4978(b).1, co-ordinates $5.7 / 84.5$. Overall diameter $86 \times 112 \mu \mathrm{m}$. (Interference contrast.)

4. Slide CSA $1725 / 2$, MPK 1034. Overall diameter $70 \times 96 \mu \mathrm{m}$.

5. Slide CSA $1725 / 2$, MPK 1035. Overall diameter $89 \times 101 \mu \mathrm{m}$.

Figures 6,7 Conosphaeridium striatoconus (Deflandre and Cookson).

6. Slide SOEKOR 4986(b).1, co-ordinates 5.1/95.7. Shell diameter $72 \times 64 \mu \mathrm{m}$, processes up to $15 \mu \mathrm{m}$. Note archeopyle to the northwest, and distal truncation of the processes.

7. Slide SOEKOR 4985(b), co-ordinates 8.0/116.1. Diameter $28 \times 34 \mu \mathrm{m}$.

Figure $8 \quad$ Chlamydophorella albertii (Neale and Sarjeant). Slide CSA 1758/1, MPK 1067. Overall diameter $67 \times 44 \mu \mathrm{m}$.

Figures 9, 10 Chlamydophorella huguonioti (Valensi). Slide CSA $1733 / 1$, MPK 1068. Shell diameter $38 \times 39 \mu \mathrm{m}$, processes $6-10 \mu \mathrm{m}$. Note enveloping membrane.

9. Interference contrast.

Figure 11 Cleistosphaeridium polypes (Cookson and Eisenack). Slide CSA 1733/1, MPK 1069. Shell diameter $41 \times 34 \mu \mathrm{m}$, processes $10-18 \mu \mathrm{m}$.

Figure 12 Cleistosphaeridium cf. huguonioti (Valensi). Slide CSA $1754 / 1$, MPK 1080. Shell diameter $54 \times 58$ $\mu \mathrm{m}$, processes 3-6 $\mu \mathrm{m}$. Note relatively short processes not supporting a membrane.

Figure 13 Cleistosphaeridium flexuosum Davey et al. Slide CSA $1735 / 1$, MPK 1063. Shell diameter $44 \times 42$ $\mu \mathrm{m}$, processes up to $12 \mu \mathrm{m}$. (Phase contrast.)

Figures 14, 15 Cribroperidinium edwardsi (Cookson and Eisenack).

14. Slide CSA 1733/2, MPK 1082. Apical view.

15. Slide CSA 1733/1, MPK 1070. Detached operculum ( $\left.3^{\prime \prime}\right)$. 
PLATE 2

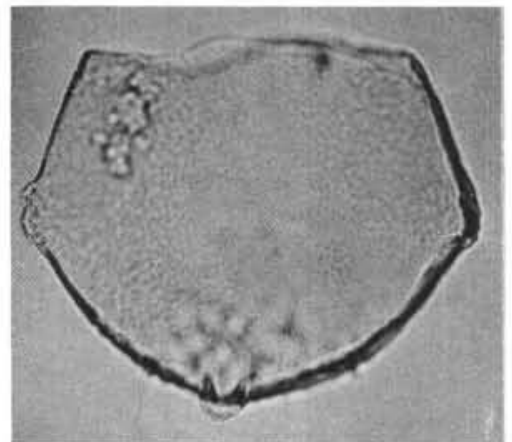

1

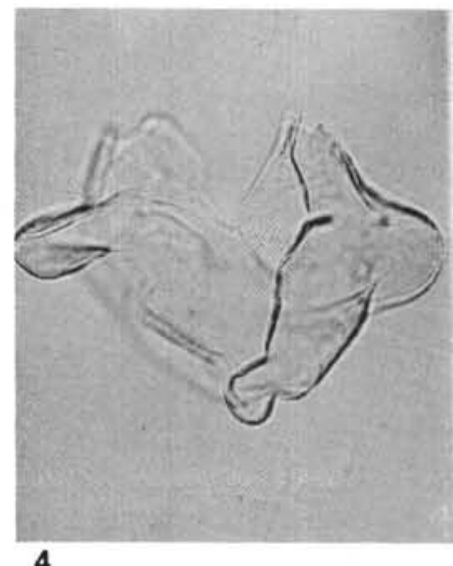

4

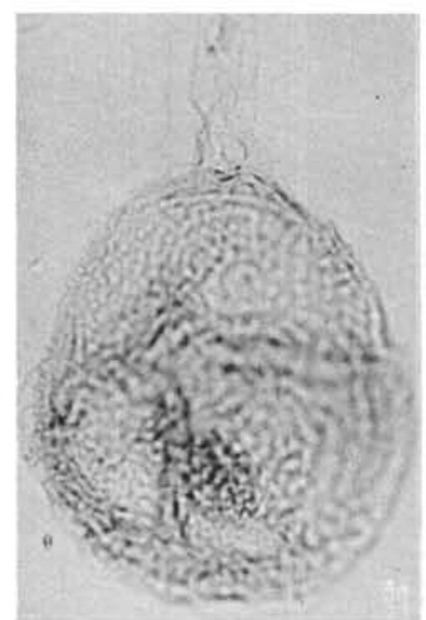

8

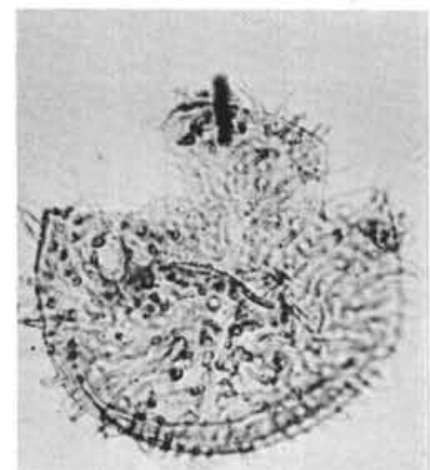

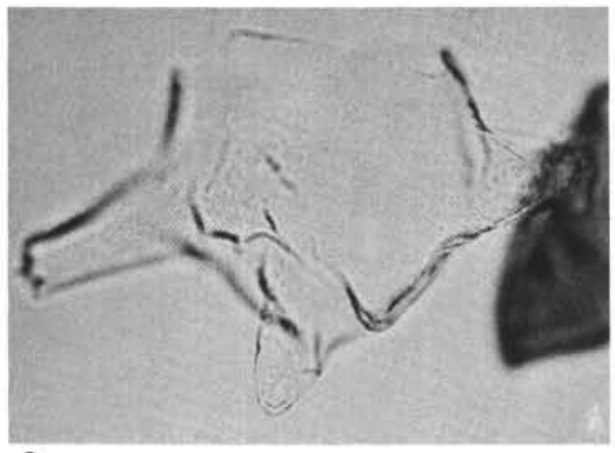

2
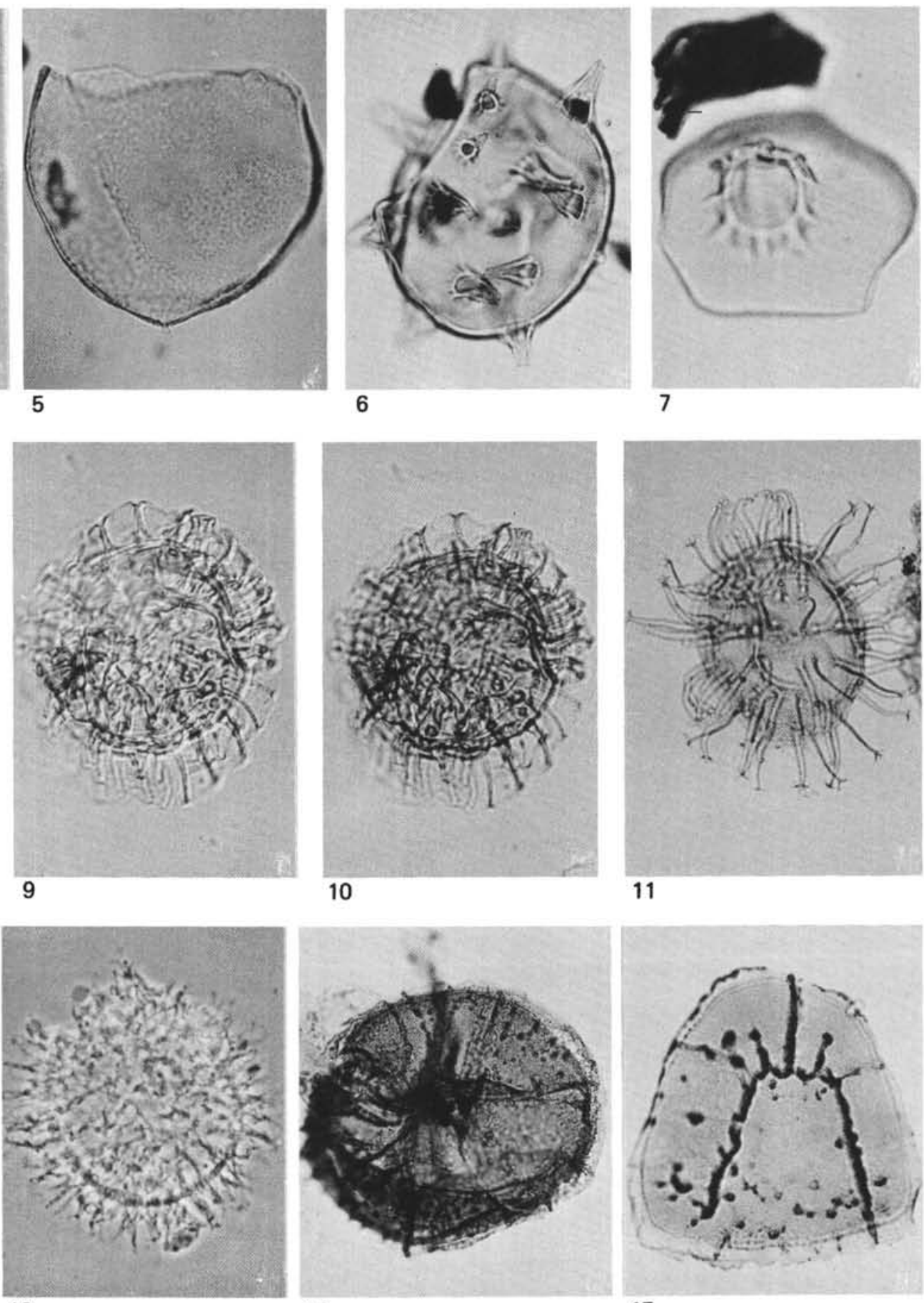

14

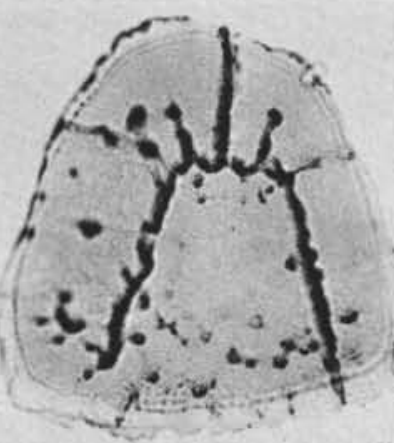

15 


\section{PLATE 3}

Figures 1,2 Cyclonephelium ?attadalicum Cookson and Eisenack. Slide CSA 1726/2, MPK 1083. Overall diameter $67 \times 56 \mu \mathrm{m}$.

1. Dorsal surface.

2. Ventral surface.

Figure 3 "Canningia" cf. scabrosa Cookson and Eisenack. Slide CSA 1732/1, MPK 1051. Overall diameter $62 \times 73 \mu \mathrm{m}$.

Figures 4, 7,8 Cyclonephelium distinctum subsp. longispinatum nov.

4. Slide CSA 1733/1, MPK 1071. Shell diameter $53 \times 60 \mu \mathrm{m}$, processes up to $12 \mu \mathrm{m}$. Some of the processes are membranous, and such forms could well grade into C. compactum.

7. Type.

8. Slide CSA 1732/1, MPK 1052. Shell diameter $48 \times 54 \mu \mathrm{m}$, processes up to $16 \mu \mathrm{m}$.

Figure 5 Cyclonephelium compactum Deflandre and Cookson. Slide SOEKOR 4991(b).1, co-ordinates $15.7 / 84.2$. Shell diameter $63 \times 70 \mu \mathrm{m}$, crests up to $15 \mu \mathrm{m}$.

Figure 6 Cyclonephelium cf. compactum Deflandre and Cookson. Slide SOEKOR 4986(b).1, co-ordinates $9.2 / 85.7$. Shell diameter $70 \times 85 \mu \mathrm{m}$, crests up to 5 $\mu \mathrm{m}$. A single specimen with low crests.

Figures 9,12 Cyclonephelium distinctum subsp. distinctum Deflandre and Cookson.

9. Slide SOEKOR 4985(b), co-ordinates 9.4/97.1. Shell diameter $81 \times 74 \mu \mathrm{m}$, processes up to $11 \mu \mathrm{m}$.

12. Slide SOEKOR 4985(b).1, co-ordinates $22.1 / 78.0$. Shell diameter $79 \times 83 \mu \mathrm{m}$, processes up to $13 \mu \mathrm{m}$.

Figures 10,11 Cyclonephelium hystrix (Eisenack). Slide CSA $1739 / 1$, MPK 1086. Shell diameter $67 \times 75 \mu \mathrm{m}$, processes up to $7 \mu \mathrm{m}$.

10. Ventral surface.

11. Dorsal surface.

Figures 13-15 Cyclonephelium distinctum subsp. brevispinatum Millioud.

13. Slide SOEKOR 5002(b).1, co-ordinates $8.6 / 82.0$. Shell diameter $68 \times 93 \mu \mathrm{m}$, processes up to $3 \mu \mathrm{m}$.

14. Slide SOEKOR 5014(b).1, co-ordinates $4.0 / 76.0$. Shell diameter $66 \times 74 \mu \mathrm{m}$, processes up to $5 \mu \mathrm{m}$.

15. Slide CSA 1733/1, MPK 1072. Shell diameter $104 \times 99 \mu \mathrm{m}$, processes up to $5 \mu \mathrm{m}$. 
PLATE 3
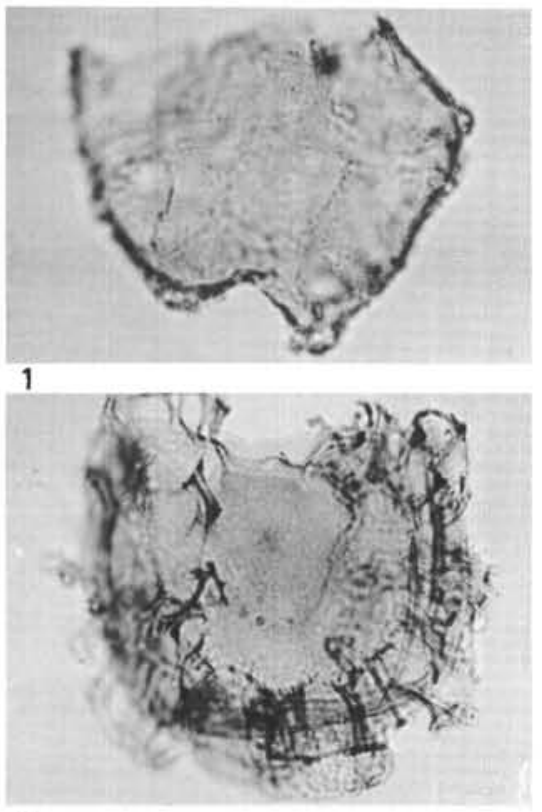

4

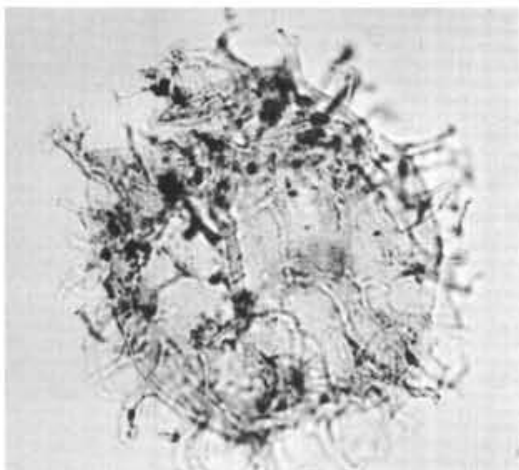

7

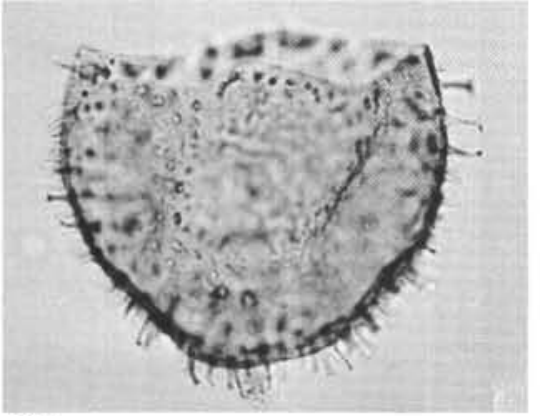

10

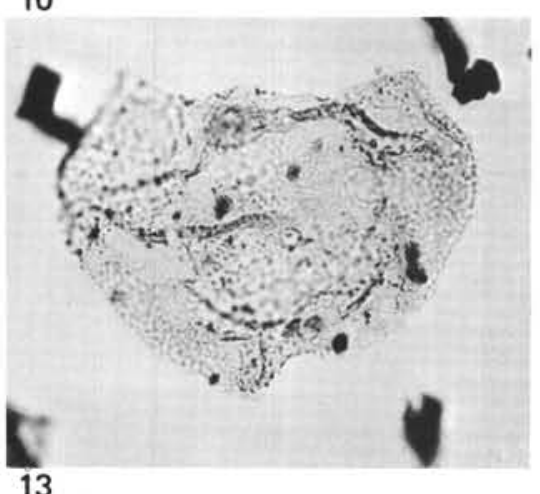

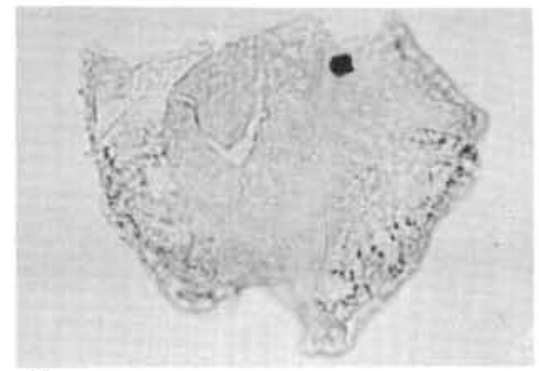

2

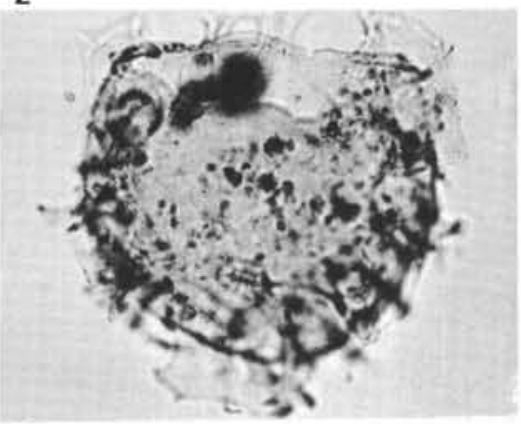

5

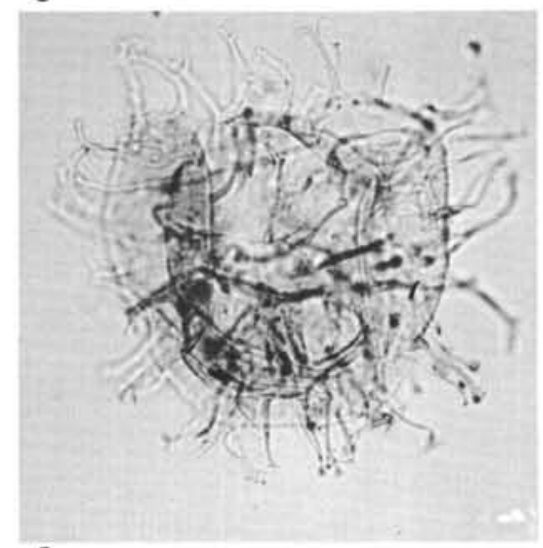

8

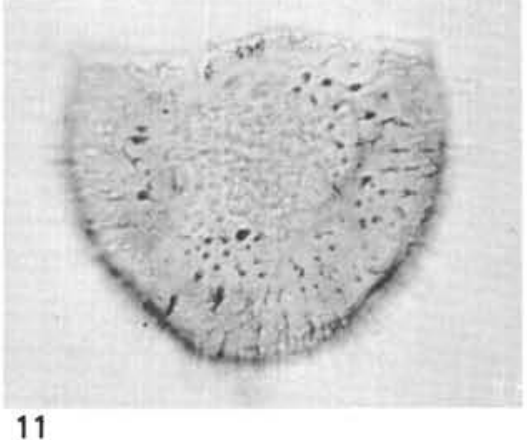

11

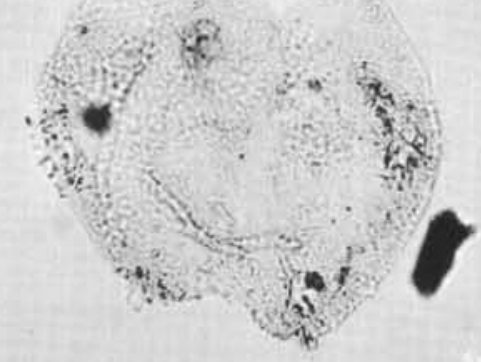

14

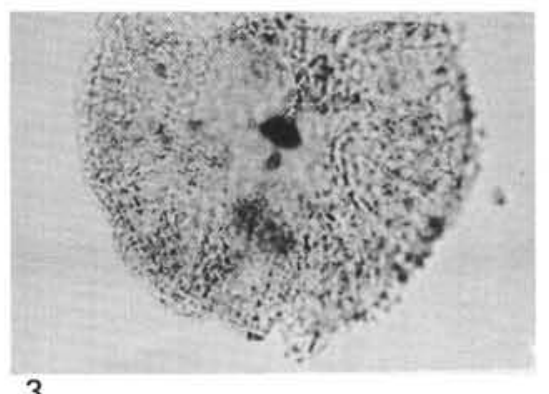

3

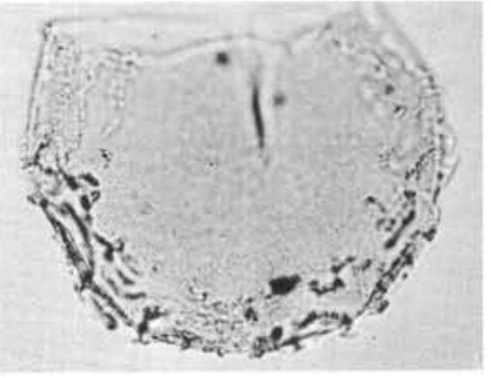

6

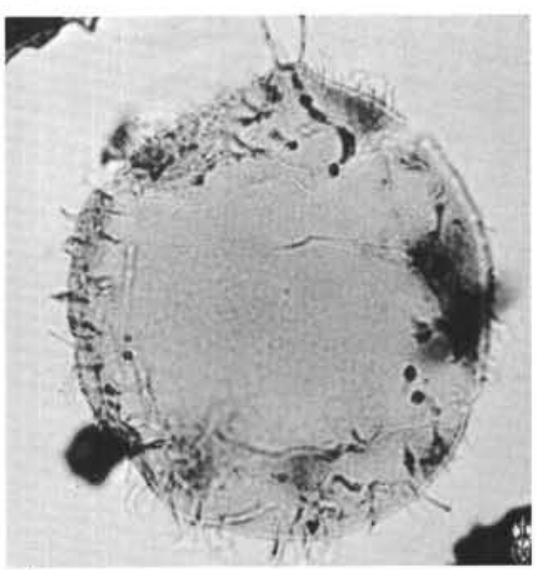

9

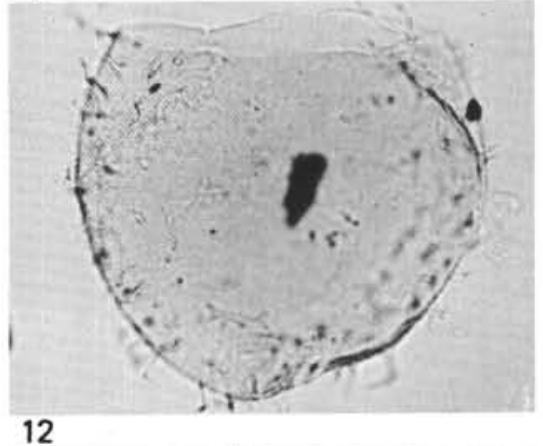

12

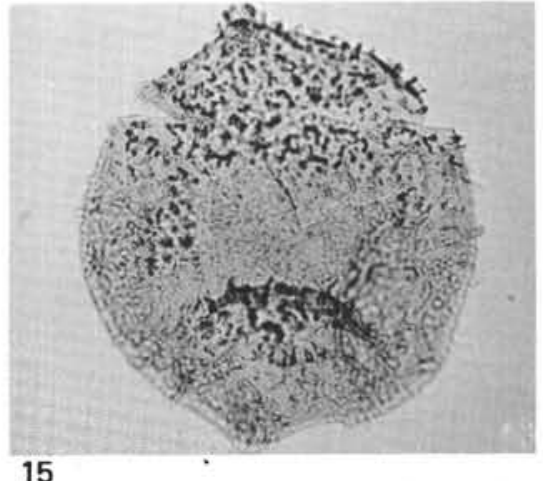




\section{PLATE 4}

Figure 1 Dingodinium cerviculum Cookson and Eisenack. Slide SOEKOR 5018(b).1, co-ordinates 13.8/93.1. Overall diameter $92 \times 59 \mu \mathrm{m}$.

Figure 2 Cribroperidinium sp. A. Slide SOEKOR 5012(b).1, co-ordinates $13.8 / 100.8$. Overall diameter $155 \times$ $103 \mu \mathrm{m}$.

Figure 3 Gonyaulacysta microceras (Eisenack). Slide SOEKOR 5023(b).1, co-ordinates 17.6/109.2. Overall diameter $81 \times 71 \mu \mathrm{m}$.

Figures 4, 7 Gonyaulacysta exilicristata Davey.

4. Slide CSA 1734/1, MPK 1089. Overall diameter $90 \times 80 \mu \mathrm{m}$.

7. Slide CSA $1732 / 1$, MPK 1053. Overall diameter $82 \times 69 \mu \mathrm{m}$.

Figures 5,6 Gonyaulacysta tenuiceras (Eisenack).

5. Slide CSA $1735 / 1$, MPK 1064. Overall diameter $92 \times 78 \mu \mathrm{m}$. Dorsal surface with 2plate precingular archeopyle.

6. Slide CSA $1735 / 1$, MPK 1065. Overall diameter $79 \times 75 \mu \mathrm{m}$. Ventral surface.

Figures 8,9 Cribroperidinium edwardsi (Cookson and Eisenack). Slide CSA 1733/1, MPK 1073. Overall diameter $157 \times 121 \mu \mathrm{m}$.

8. Ventral surface.

9. Dorsal surface, with precingular archeopyle.

Figures 10,11 Disphaeria macropyla Cookson and Eisenack. Slide CSA 1730/1, MPK 1090. Overall diameter $83 \times 70 \mu \mathrm{m}$, inner sack diameter $45 \times 34 \mu \mathrm{m}$.

10. Ventral surface.

11. Dorsal surface.

Figures 12,13 Exochosphaeridium truncigerum (Deflandre) comb. nov. Slide SOEKOR 4986(b).1, coordinates 1.8/93.1. Shell diameter $57 \times 59 \mu \mathrm{m}$, processes up to $16 \mu \mathrm{m}$.

12. Dorsal surface.

13. Ventral surface. 
PLATE 4

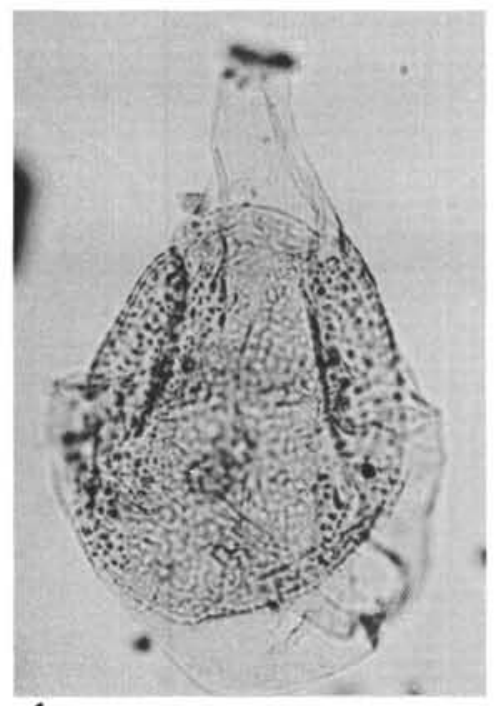

1
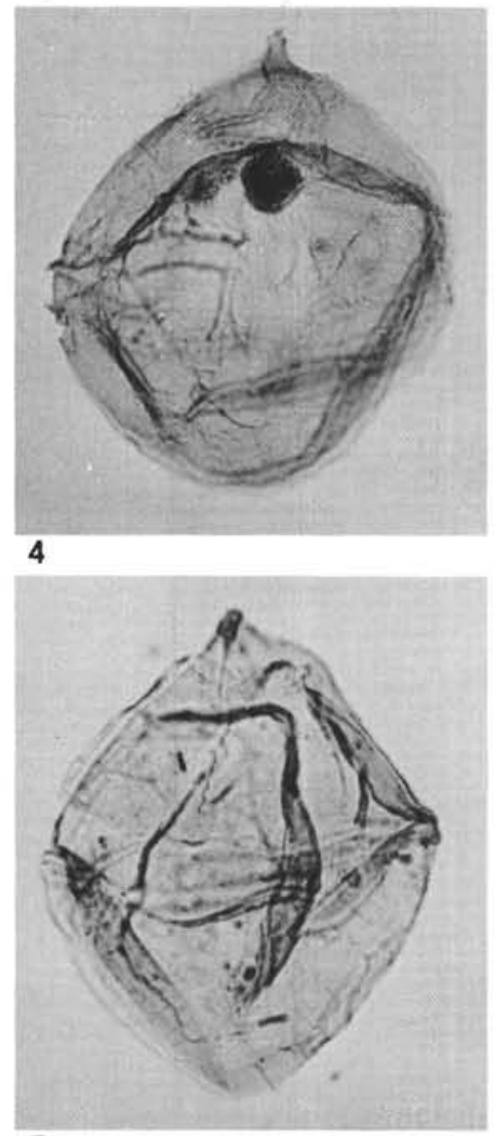

7

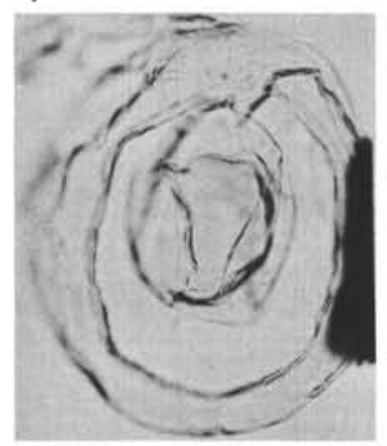

10

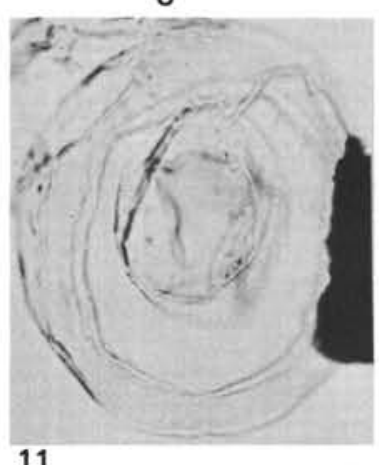

11

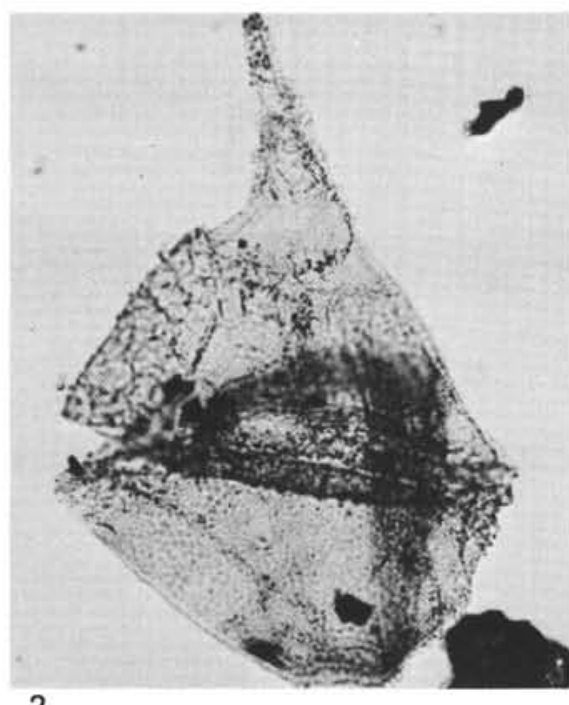

2

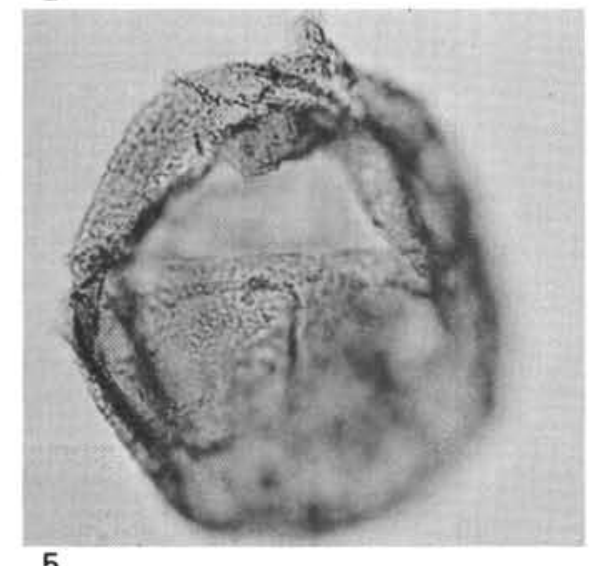

5

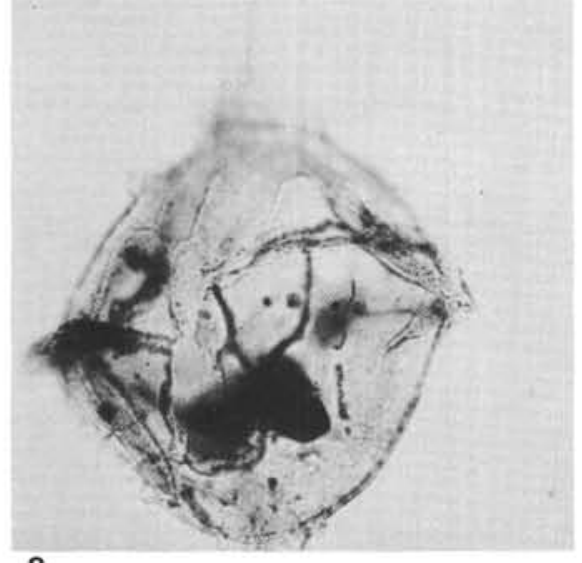

8

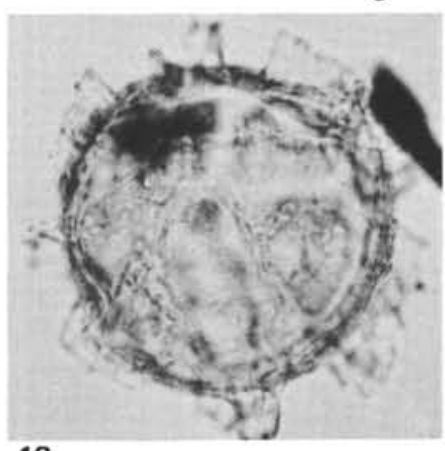

12
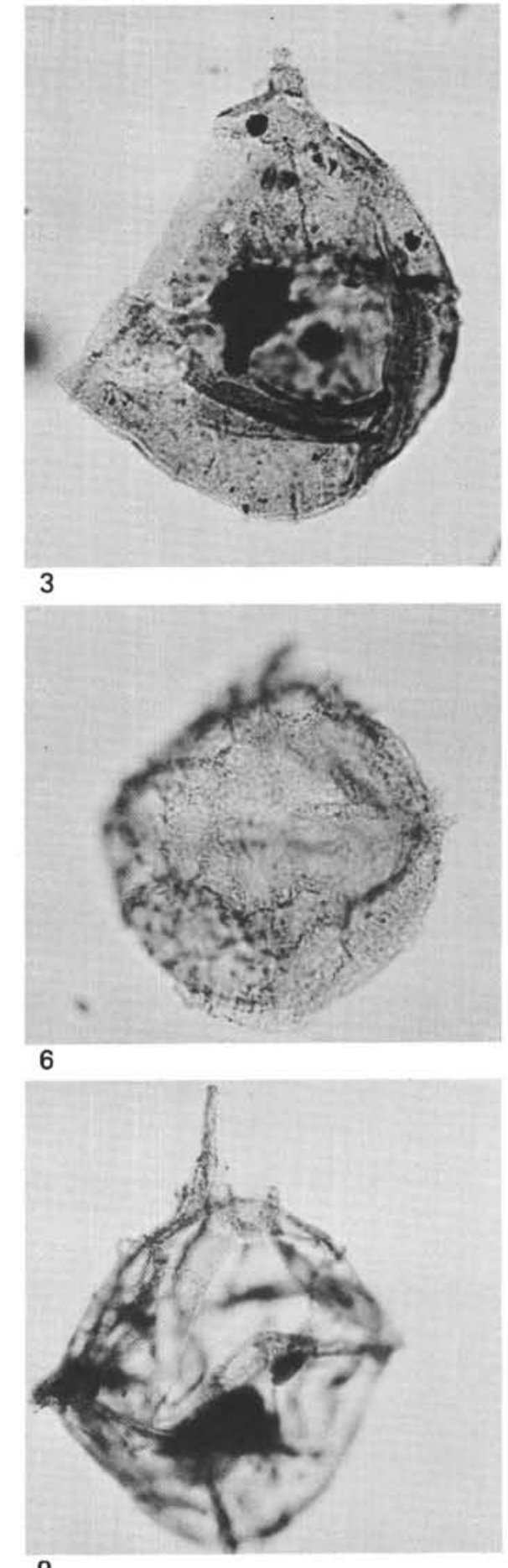

9

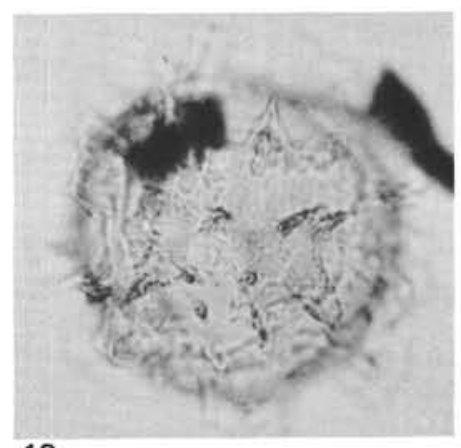


PLATE 5

Figure $1 \quad$ Hystrichodinium pulchrum Deflandre.

Slide CSA $1732 / 1$, MPK 1054.

Shell diameter $54 \times 46 \mu \mathrm{m}$, processes up to $22 \mu \mathrm{m}$.

Figure 2 Exochosphaeridium phragmites Davey et al.

Slide CSA $1733 / 1$, MPK 1074.

Shell diameter $70 \times 69 \mu \mathrm{m}$, processes up to $17 \mu \mathrm{m}$.

Figure $3 \quad$ Kleithriasphaeridium simplicispinum (Davey and Williams).

Slide CSA 1754/1, MPK 1081.

Shell diameter $55 \times 47 \mu \mathrm{m}$, processes $15-22 \mu \mathrm{m}$.

Figure $4 \quad$ Hystrichosphaeridium sp. A.

Slide CSA 1726/1, MPK 1047.

Shell diameter $46 \times 51 \mu \mathrm{m}$, processes up to $16 \mu \mathrm{m}$.

Figures 5,6 ?Maduradinium sp. A.

5. Slide CSA 1733/1, MPK 1075.

Shell diameter $54 \times 59 \mu \mathrm{m}$.

6. Slide CSA $1732 / 1$, MPK 1055 .

Shell diameter $62 \times 63 \mu \mathrm{m}$.

Figure $7 \quad$ Paredonia ceratophora Deflandre.

Slide CSA 1739/1, MPK 1087.

Overall diameter $95 \times 56 \mu \mathrm{m}$.

Figures 8,9 Membranilarnacia polycladiata Cookson and Eisenack.

Slide SOEKOR 4989(b).1.

8. Co-ordinates $17.8 / 85.5$. Overall diameter 56 $\times 60 \mu \mathrm{m}$.

Lateral view.

9. Co-ordinates 20.2/106.7. Overall diameter 53 $\times 59 \mu \mathrm{m}$.

Apical-ventral view showing sulcal notch of archeopyle.

Figure 10 Oligosphaeridium cf. complex (White).

Slide CSA 1726/1, MPK 1048.

Shell diameter $40 \times 42 \mu \mathrm{m}$, processes up to $16 \mu \mathrm{m}$.

Note wide distal expansions of the processes.

Figures 11,12 Meiourogonyaulax cf. bulloidea (Cookson and Eisenack).

Slide SOEKOR 5023(b).1, co-ordinates 2.1/103.0.

Shell diameter $107 \times 103 \mu \mathrm{m}$, crests up to $7 \mu \mathrm{m}$.

11. Ventral surface.

12. Dorsal surface.

Figure $13 \quad$ Oligosphaeridium complex (White).

Slide CSA 1732/1, MPK 1056.

Shell diameter $42 \times 43 \mu \mathrm{m}$, processes $20-30 \mu \mathrm{m}$. 
PLATE 5
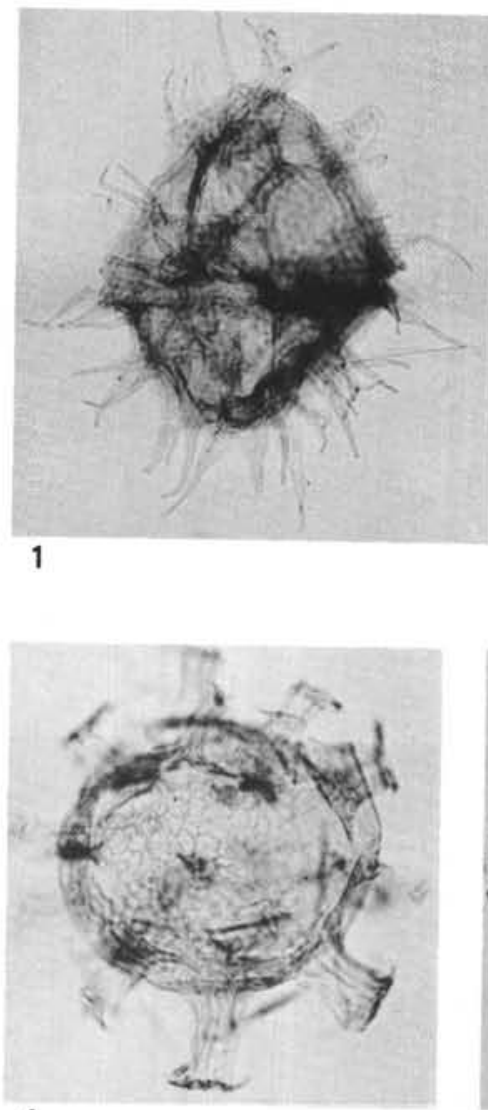

4
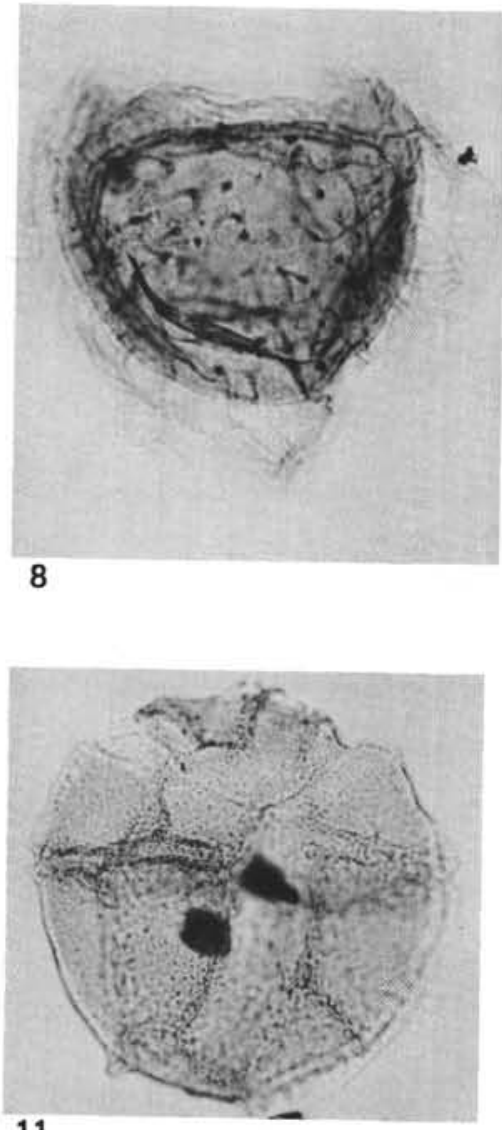

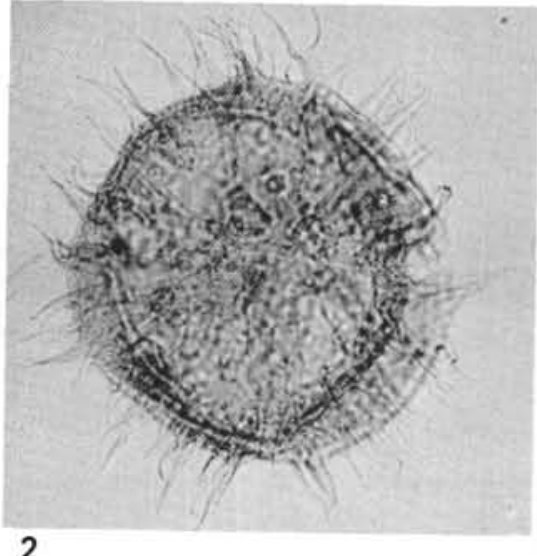

2

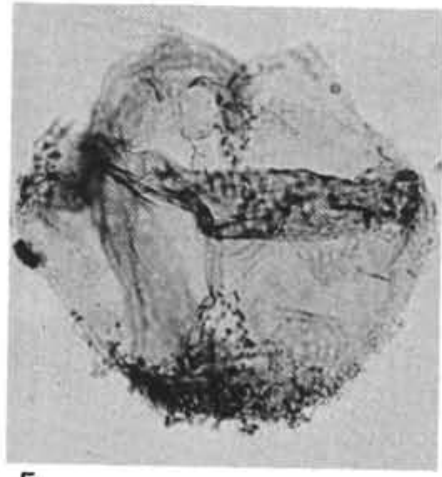

5
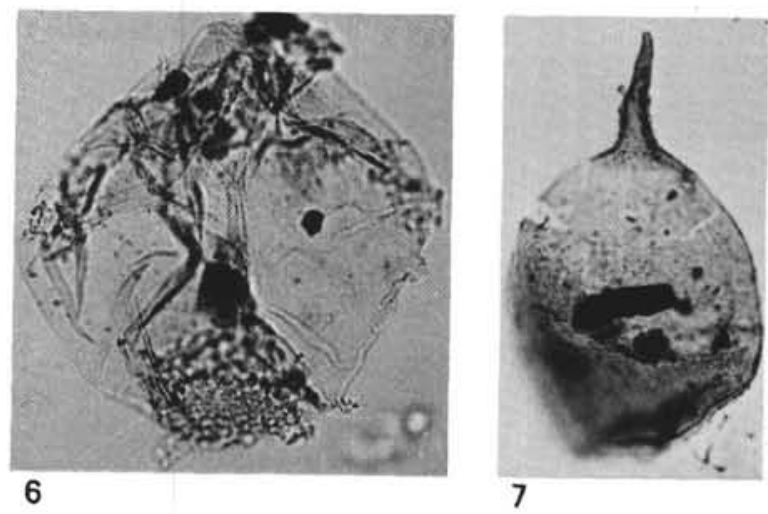
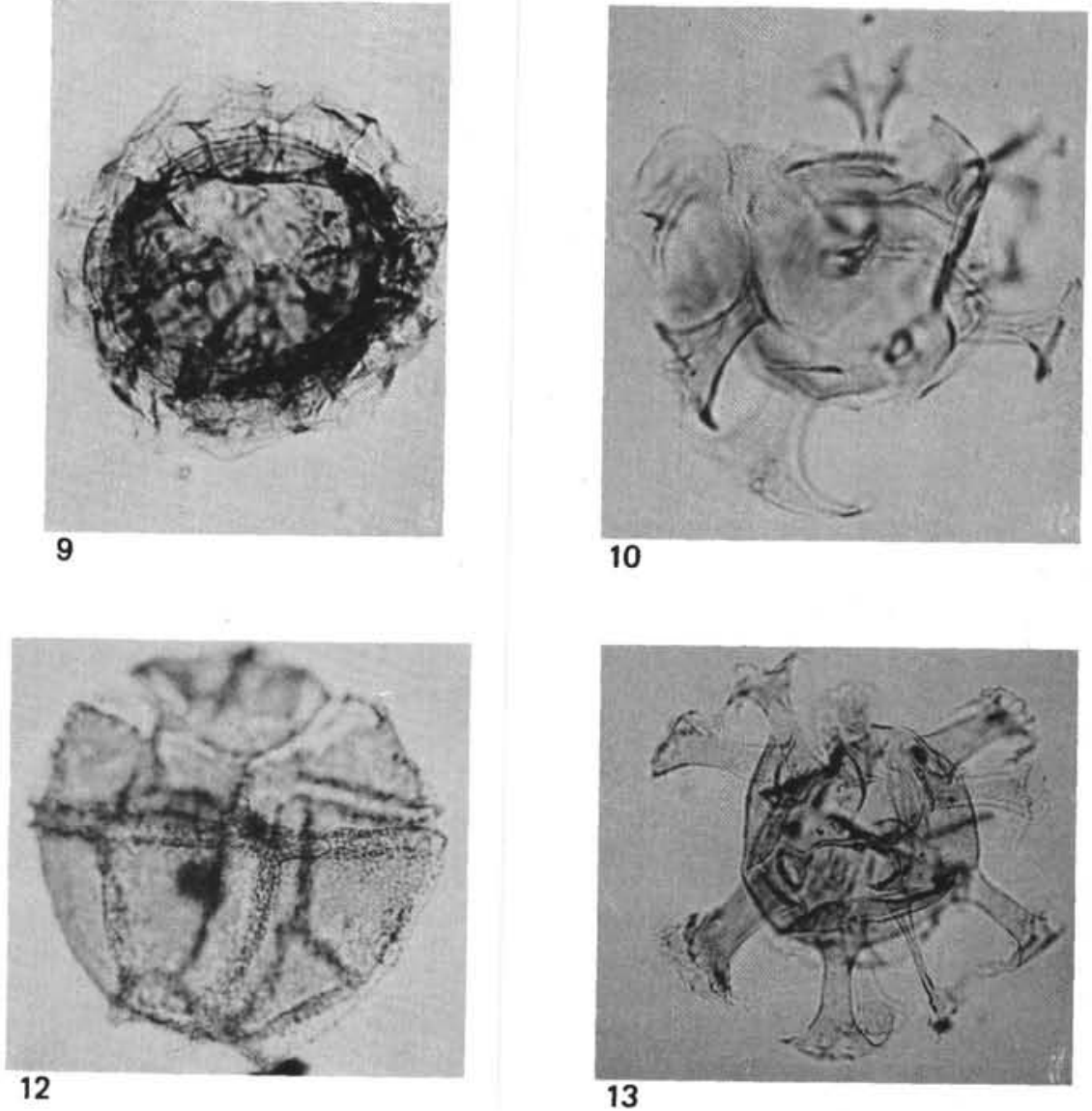


\section{PLATE 6}

Figures 1, 7 Odontochitina porifera Cookson.

1. Slide SOEKOR 4983(b).1, co-ordinates 14.3/91.6.

Overall length $108 \mu \mathrm{m}$, horn length $85 \mu \mathrm{m}$.

7. Slide CSA 1725/2, MPK 1036.

Shell diameter $50 \times 63 \mu \mathrm{m}$, horn lengths 68 and $75 \mu \mathrm{m}$.

Figure 2 Odontochitina cribropoda Deflandre and Cookson. Slide CSA 1729/1, MPK 1091.

Overall length $108 \mu \mathrm{m}$, horn length (broken) 69 $\mu \mathrm{m}$.

Figure 3 Muderongia tetracantha (Gocht).

Slide SOEKOR 4998(b).1, co-ordinates $16.3 / 118.2$.

Shell diameter $59 \times 55 \mu \mathrm{m}$, antapical horn $45 \mu \mathrm{m}$, lateral horns 60 and $35 \mu \mathrm{m}$.

Figure $4 \quad$ Odontochitina costata Alberti.

Slide CSA 1733/1, MPK 1076.

Shell diameter $67 \times 65 \mu \mathrm{m}$, horn lengths 112 and $130 \mu \mathrm{m}$.

Figure 5 Xenascus ceratioides (Deflandre).

Slide CSA 1732/1, MPK 1057.

Shell diameter $71 \times 62 \mu \mathrm{m}$, horn lengths 50 and 35 $\mu \mathrm{m}$.

Figure $6 \quad$ Muderongia cf. staurota Sarjeant.

Slide CSA 1751/1, MPK 1041.

Shell diameter $78 \times 60 \mu \mathrm{m}$, antapical horn $52 \mu \mathrm{m}$. lateral horns 11 and $40 \mu \mathrm{m}$.

Figures 8,9 Spiniferites ramosus subsp. A.

8. Slide SOEKOR 5018(b).1, co-ordinates $3.2 / 84.2$. Shell diameter $61 \times 48 \mu \mathrm{m}$, processes up to $10 \mu \mathrm{m}$. Specimen with numerous short sutural processes.

9. Slide SOEKOR 4991(b).1, co-ordinates 19.2/101.5. Shell diameter $48 \times 39 \mu \mathrm{m}$, processes up to $10 \mu \mathrm{m}$. 
PLATE 6

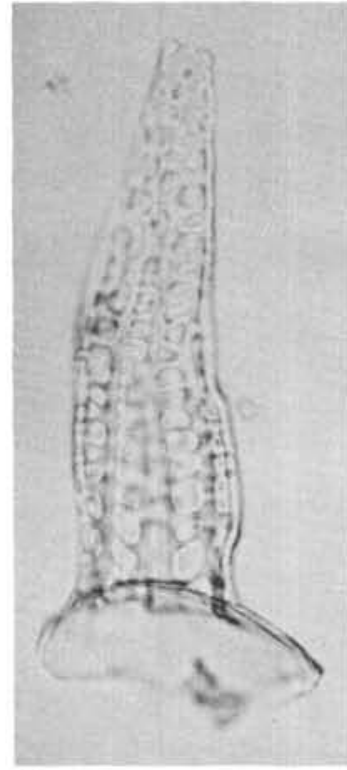

1

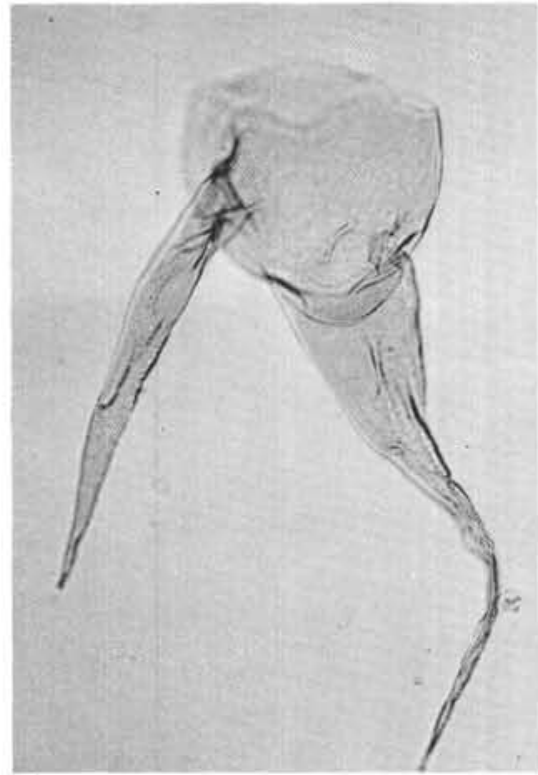

4

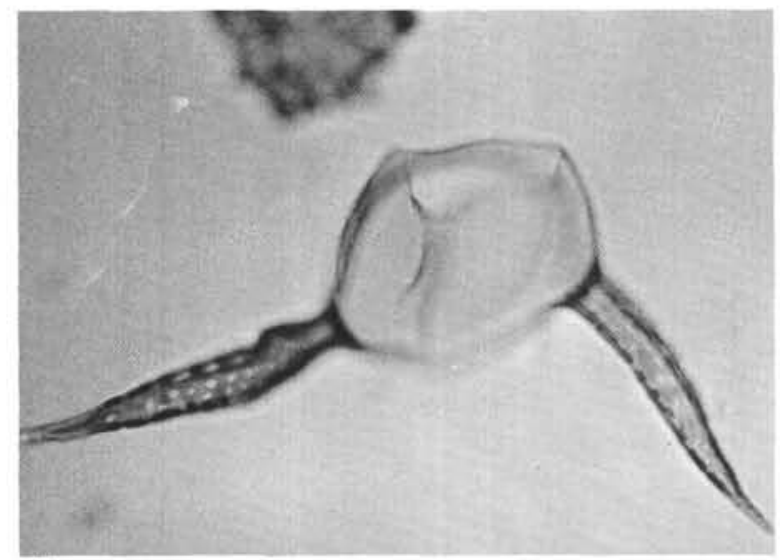

5
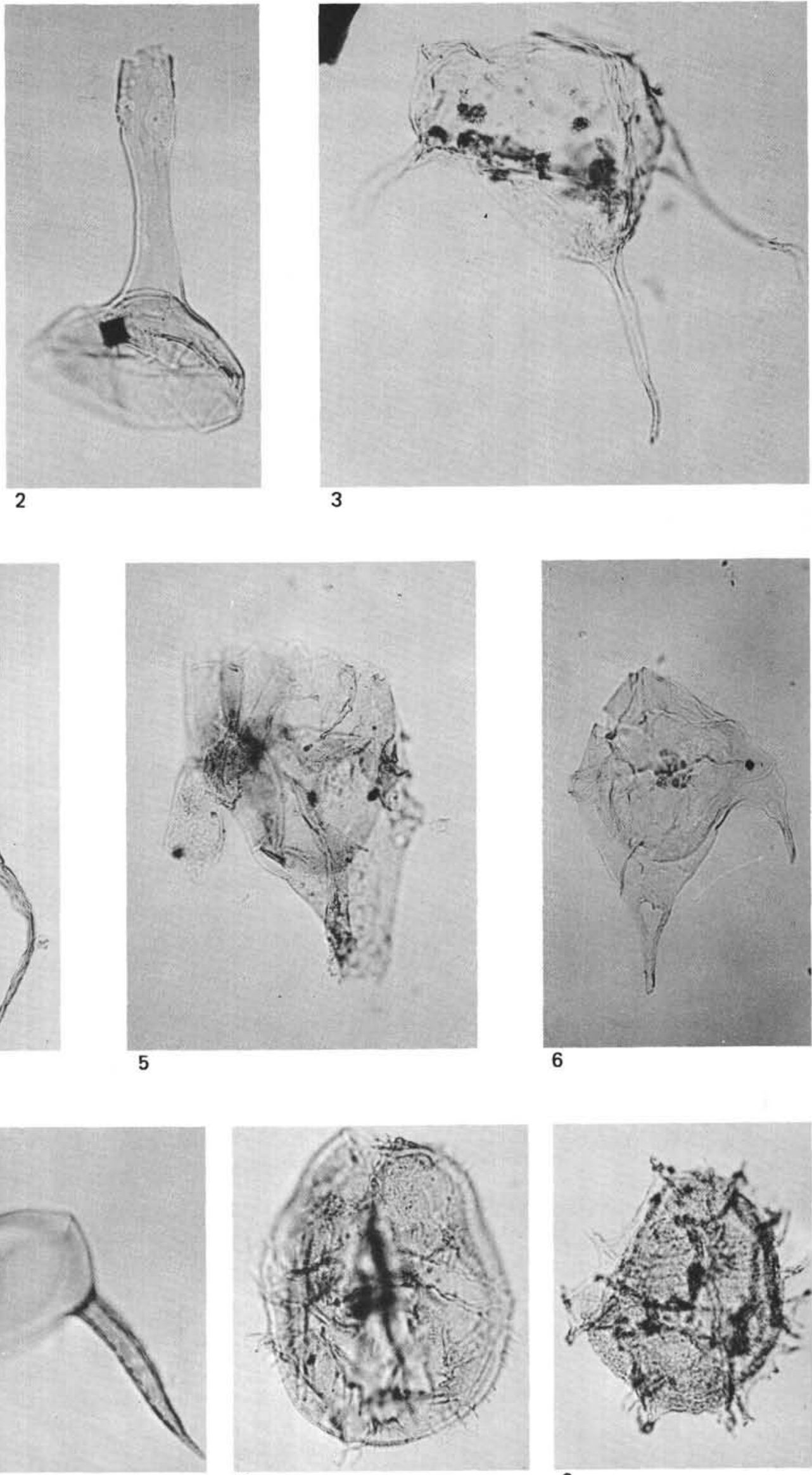

8

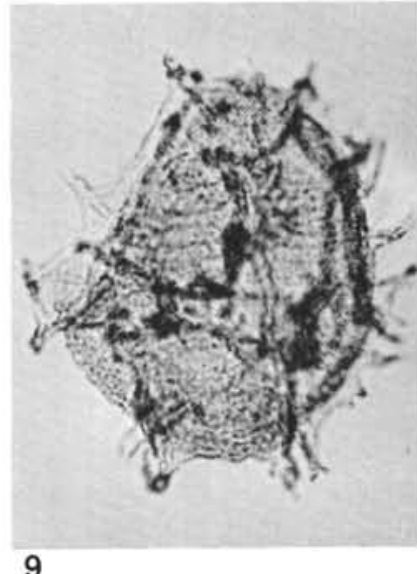




\section{PLATE 7}

Figures 1, 7 Alterbia ingrami (Cookson and Eisenack).

Slide CSA $1733 / 1$.

1. MPK 1077. Overall diameter $89 \times 57 \mu \mathrm{m}$. (Phase contrast.)

7. MPK 1078. Overall diameter $73 \times 52 \mu \mathrm{m}$.

Figure $2 \quad$ Isabelia cf. ?amphiata (McIntyre).

Slide CSA 1727/1, MPK 1092.

Overall diameter $83 \times 37 \mu \mathrm{m}$.

Figures 3-6 Chatangiella tripartita (Cookson and Eisenack).

3. Slide CSA 1726/2, MPK 1084.

Overall diameter $94 \times 52 \mu \mathrm{m}$. Ventral surface.

6. Same as Figure 3.

Dorsal surface.

4. Slide CSA 1726/1, MPK 1049.

Overall diameter $95 \times 64 \mu \mathrm{m}$. Dorsal surface.

5. Ventral surface.

Figures 8,9 Chatangiella cf. victoriensis (Cookson and Manum).

8. Slide SOEKOR 4985(b), co-ordinates 14.6/93.8. Overall diameter $87 \times 60 \mu \mathrm{m}$.

9. Slide SOEKOR 4985(b).1, co-ordinates $15.6 / 102.3$. Overall diameter $92 \times 66 \mu \mathrm{m}$. 


\section{PLATE 7}
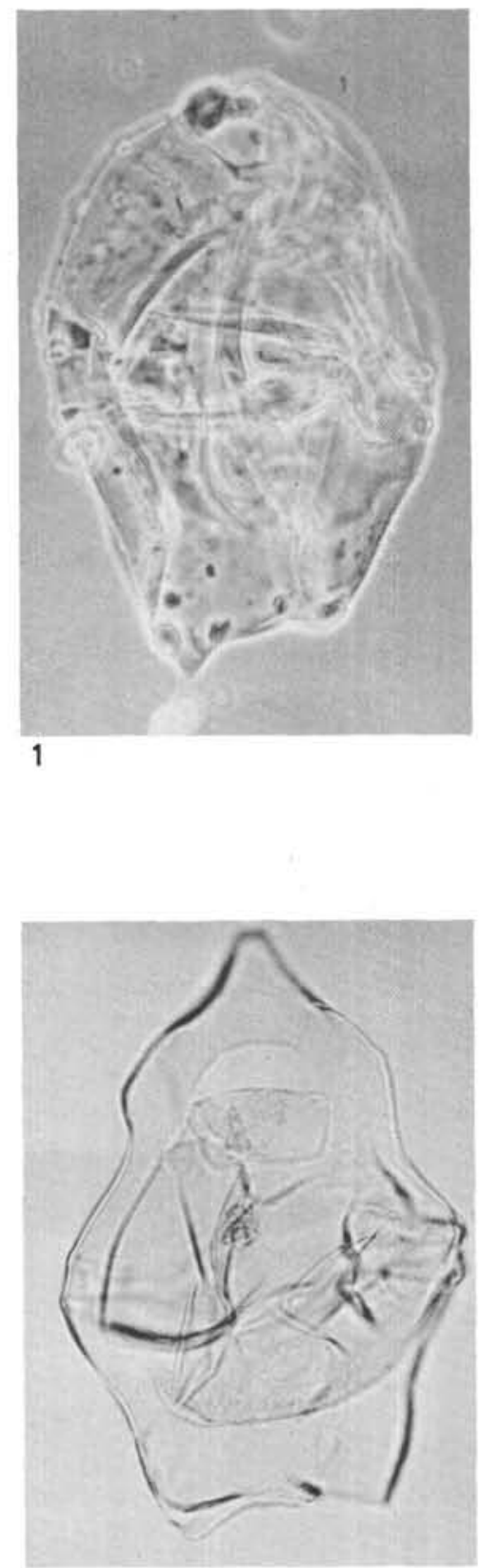

4

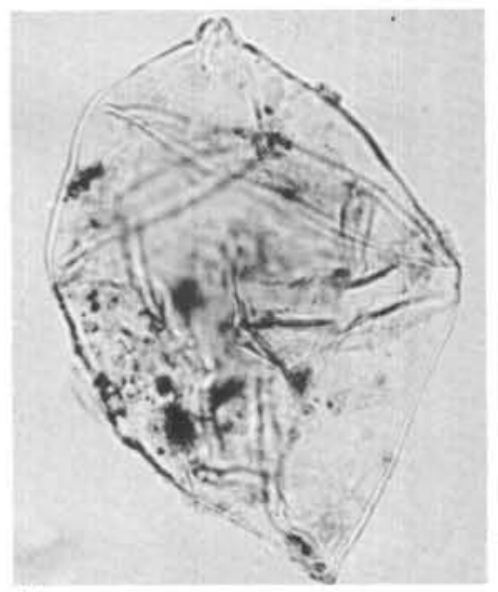

7

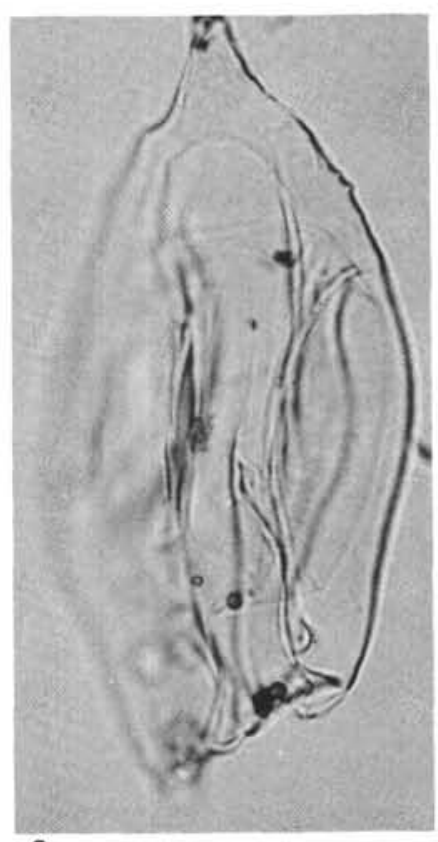

2

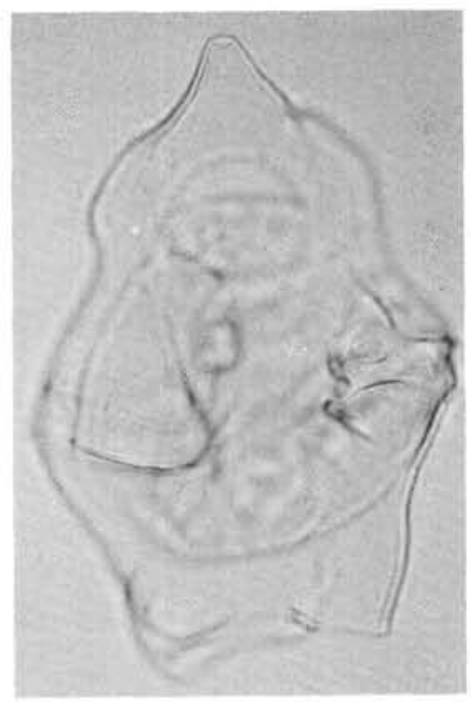

5

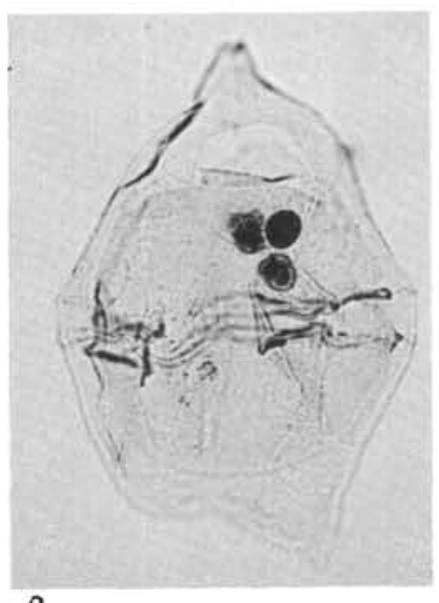

8

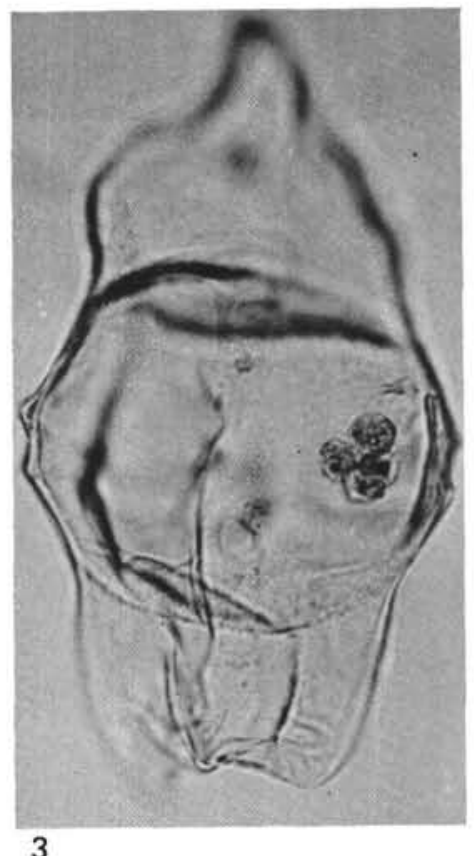

3
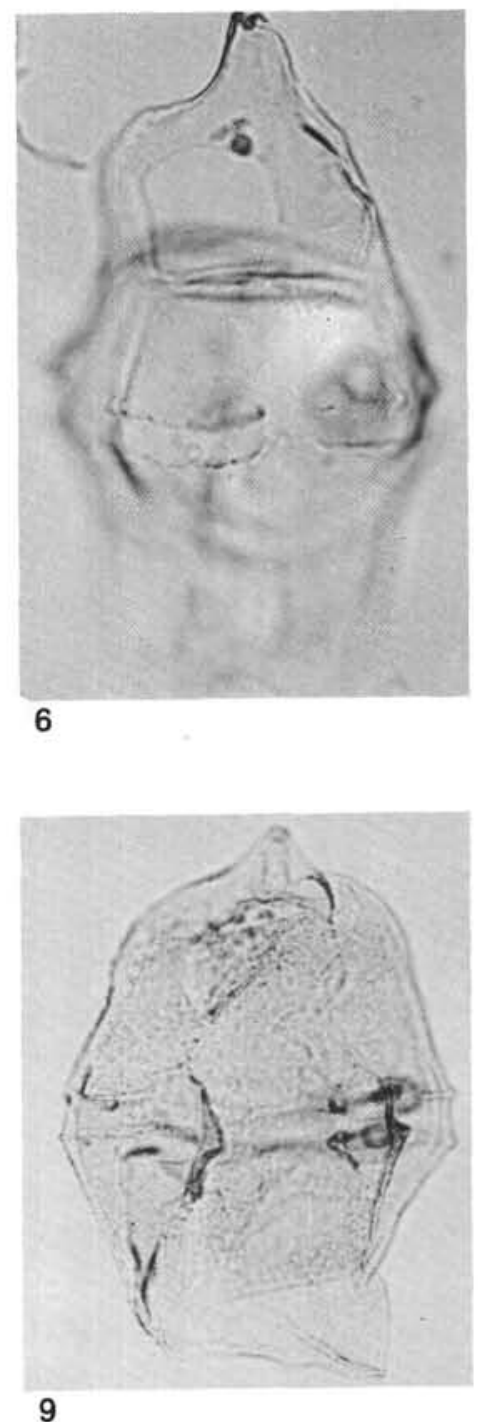


\section{PLATE 8}

Figures 1-4 Subtilisphaera ventriosa (Alberti).

1, 2. Slide SOEKOR 4998(b).1, co-ordinates $8.1 / 116.5$

Overall diameter $72 \times 54 \mu \mathrm{m}$.

1. Interference contrast.

3. Slide CSA 1741/1, MPK 1093.

Overall diameter $61 \times 52 \mu \mathrm{m}$.

4. Slide CSA 1741/1, MPK 1094. Overall diameter $65 \times 52 \mu \mathrm{m}$.

Figure $5 \quad$ Palaeoperidinium pyrophorum (Ehrenberg).

Slide CSA 1733/1, MPK 1079.

Overall diameter $84 \times 73 \mu \mathrm{m}$. (Phase contrast.)

Figure $6 \quad$ Palaeoperidinium cretaceum Pocock.

Slide CSA 1735/1, MPK 1066.

Overall diameter $77 \times 65 \mu \mathrm{m}$.

Note lack of second antapical horn. (Phase contrast.)

Figure $7 \quad$ Subtilisphaera pirnaensis (Alberti). Slide CSA 1732/1, MPK 1058.

Overall diameter $87 \times 60 \mu \mathrm{m}$.

Figures 8, 9 Subtilisphaera ?ventriosa (Alberti).

Slide CSA 1736/1, MPK 1044.

Overall diameter $62 \times 52 \mu \mathrm{m}$.

8. Phase contrast.

9. Interference contrast.

Figure $10 \quad$ Nelsoniella aceras Cookson and Eisenack.

Slide CSA 1725/2, MPK 1037.

Overall diameter $67 \times 69 \mu \mathrm{m}$.

Figure 11 Spinidinium echinoideum (Cookson and Eisenack), Slide CSA 1725/1, MPK 1095.

Overall diameter $54 \times 46 \mu \mathrm{m}$. (Phase contrast.)

Figure 12 Pareodinia ceratophora Deflandre.

Slide CSA 1739/1, MPK 1088.

Shell diameter $88 \times 44 \mu \mathrm{m}$.

Figure 13 Spinidinium lanterna Cookson and Eisenack.

Slide CSA 1732/1, MPK 1096.

Overall diameter $71 \times 51 \mu \mathrm{m}$. (Phase contrast.) 


\section{PLATE 8}

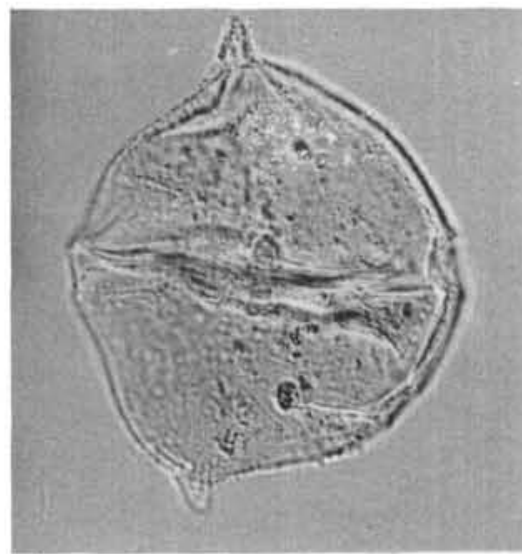

1

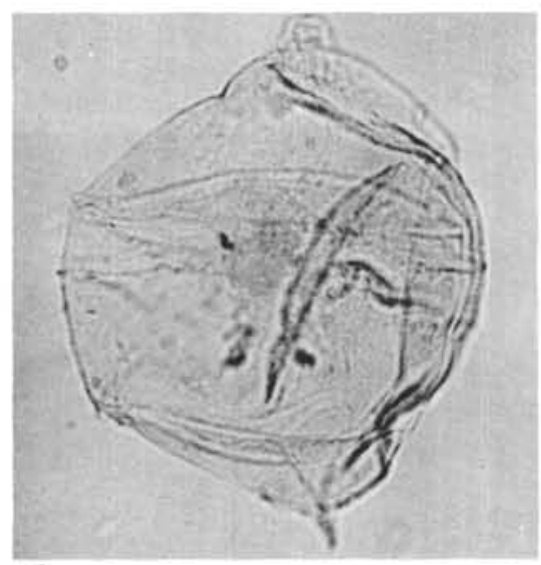

4
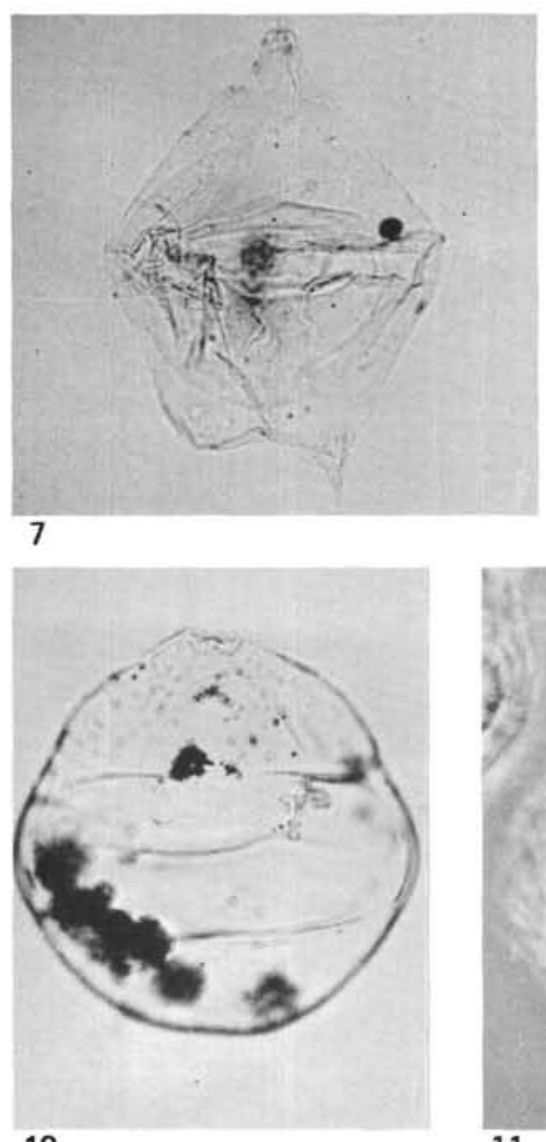

10

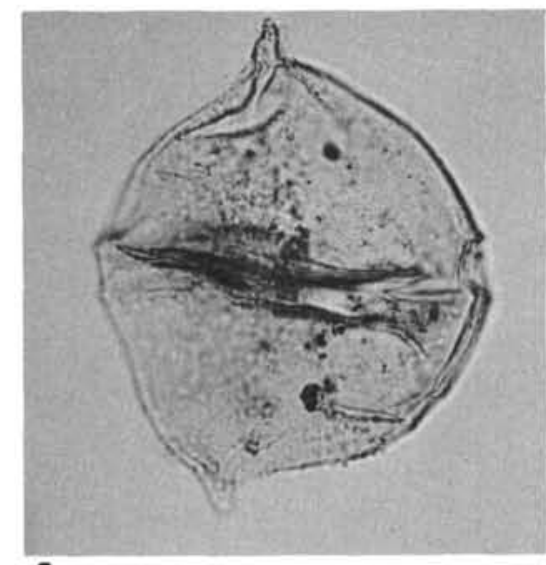

2

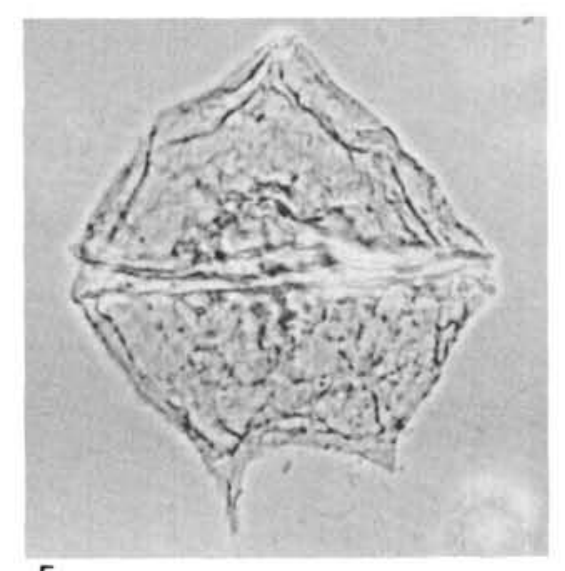

5

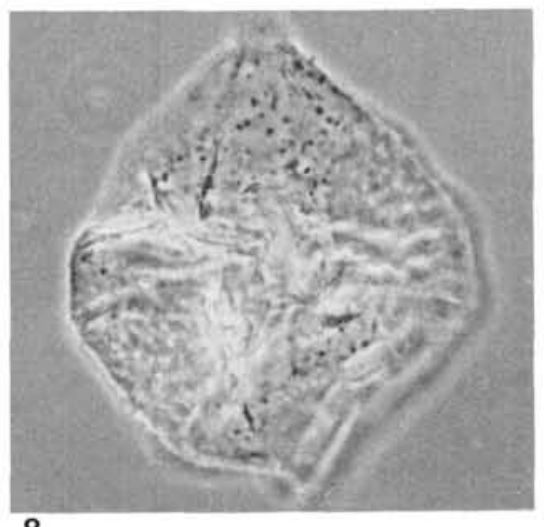

8

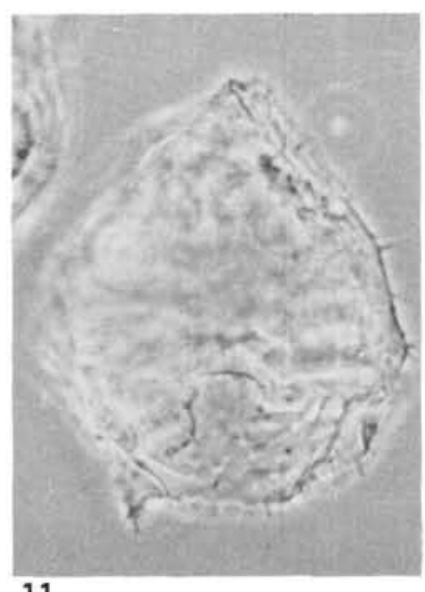

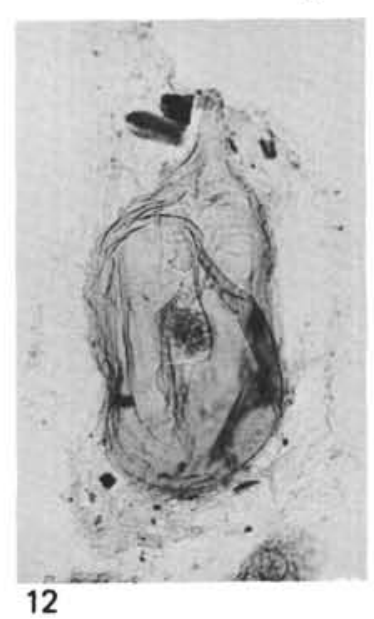

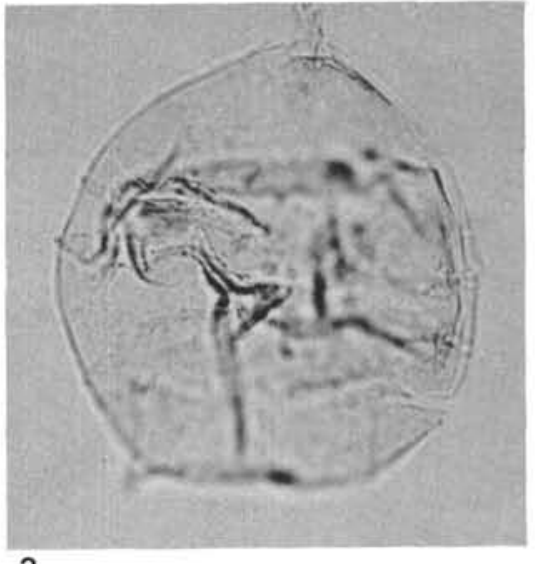

3

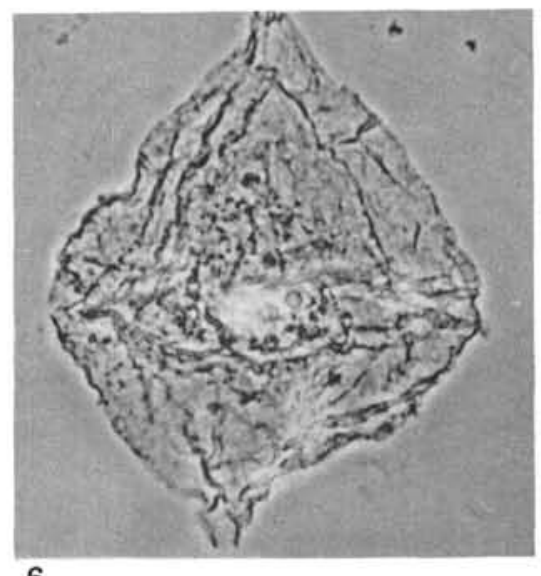

6
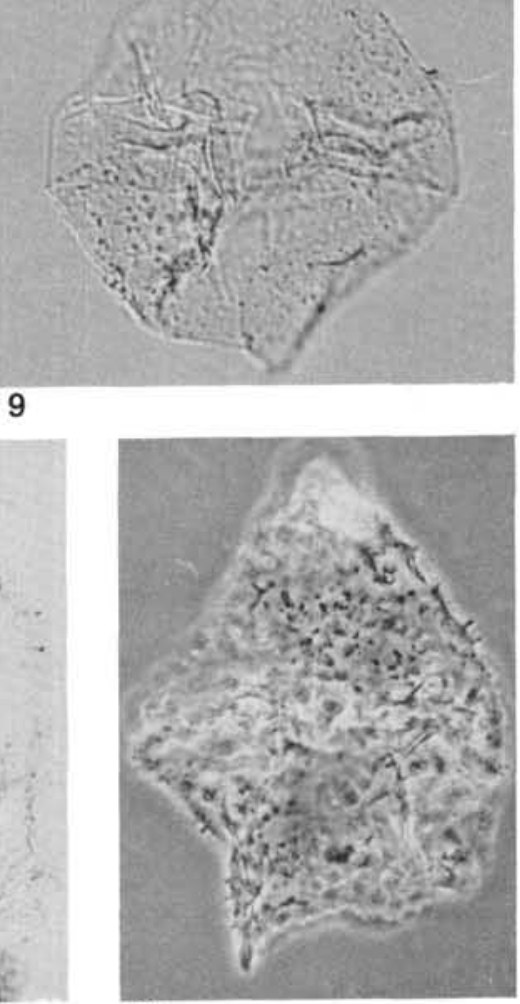
Figures 1, $10 \quad$ Systematophora sp. A.

1. Slide CSA 1759/3, MPK 1097.

Processes 17-21 $\mu \mathrm{m}$. Detached operculum with 4 processes.

10. Slide CSA $1758 / 3$, MPK 1060.

Shell diameter $49 \times 43 \mu \mathrm{m}$, processes up to 20 $\mu \mathrm{m}$.

Figure 2 Trichodinium castanea (Deflandre).

Slide CSA 1732/1, MPK 1097.

Shell diameter $50 \times 47 \mu \mathrm{m}$, processes up to $5 \mu \mathrm{m}$.

Figure 3 cf. Trichodinium sp. A.

Slide CSA 1725/2, MPK 1038.

Overall diameter $66 \times 57 \mu \mathrm{m}$.

Figures $4,8 \quad$ Organism sp. A.

Slide SOEKOR 4989(b).1, co-ordinates 18.6/95.3. Shell diameter $35 \times 21 \mu \mathrm{m}$, processes up to $20 \mu \mathrm{m}$. Only one specimen of this unusual form was recorded.

Figures 5-7 Pterospermella centrata (Cookson and Eisenack).

5. Slide SOEKOR 4998(b).1, co-ordinates $11.5 / 75.2$.

Overall diameter $78 \times 64 \mu \mathrm{m}$.

6. Slide SOEKOR 5011(b).1, co-ordinates 3.8/86.2.

Overall diameter $65 \times 63 \mu \mathrm{m}$.

7. Slide SOEKOR 5012(b).1, co-ordinates 2.3/106.7.

Overall diameter $60 \times 61 \mu \mathrm{m}$.

Figure 9 Cymatiosphaera delicata Cookson and Eisenack. Slide SOEKOR 4993(b).1, co-ordinates 13.5/107.6.

Shell diameter $59 \times 58 \mu \mathrm{m}$, crests up to $3 \mu \mathrm{m}$.

Figure 11 Eyrea nebulosa Cookson and Eisenack.

Slide SOEKOR 5018(b).1, co-ordinates 4.0/114.0.

Central palynomorph diameter $65 \times 62 \mu \mathrm{m}$.

Figures 12,13 Spinidinium sverdrupianum (Manum).

Slide CSA 1726/2, MPK 1085.

Overall diameter $82 \times 61 \mu \mathrm{m}$.

12. Dorsal surface.

13. Ventral surface.

Figures 14,15 Trithyrodinium sp. A.

14. Slide SOEKOR 4985(b), co-ordinates 20.2/80.3.

Overall diameter $41 \times 57 \mu \mathrm{m}$.

15. Slide CSA 1730/2, MPK 1098.

Overall diameter $51 \times 49 \mu \mathrm{m}$. 
PLATE 9
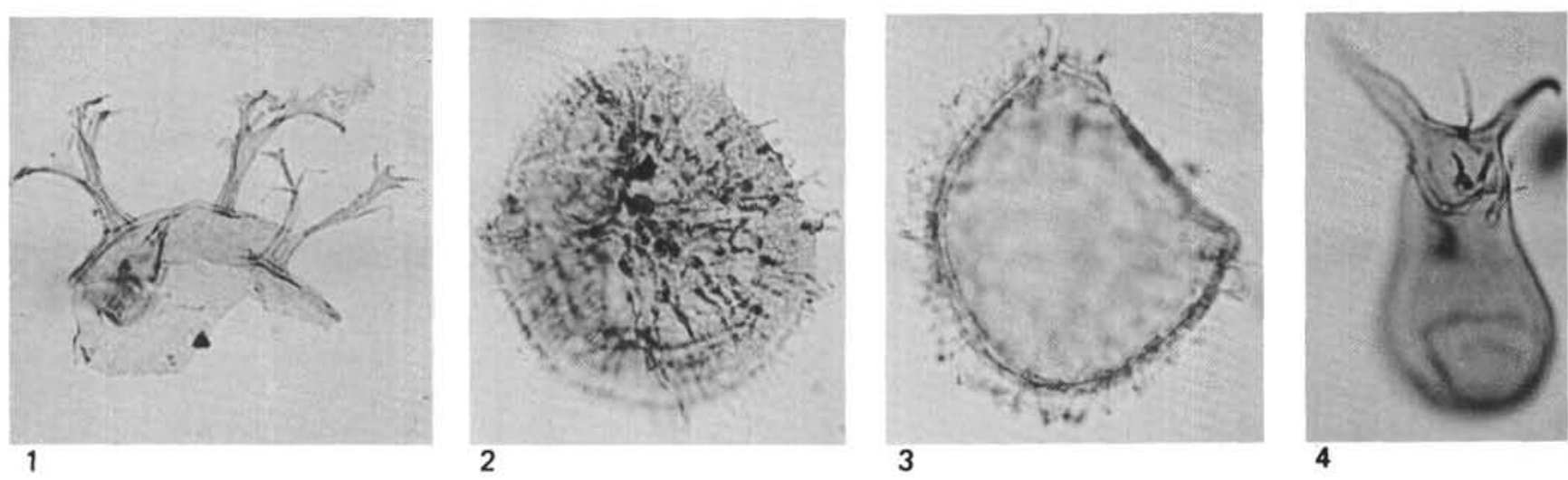

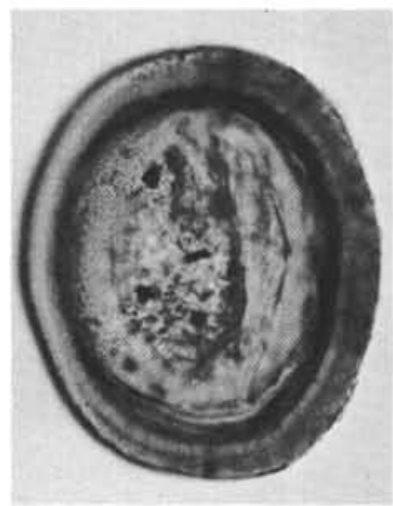

5

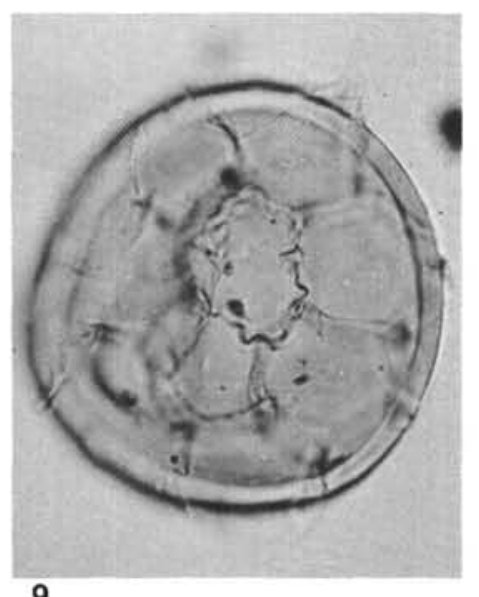

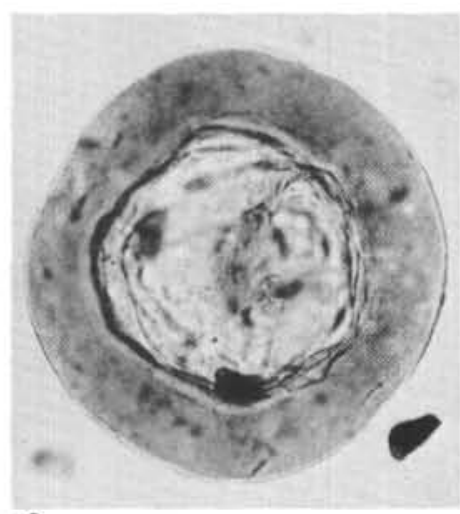

6
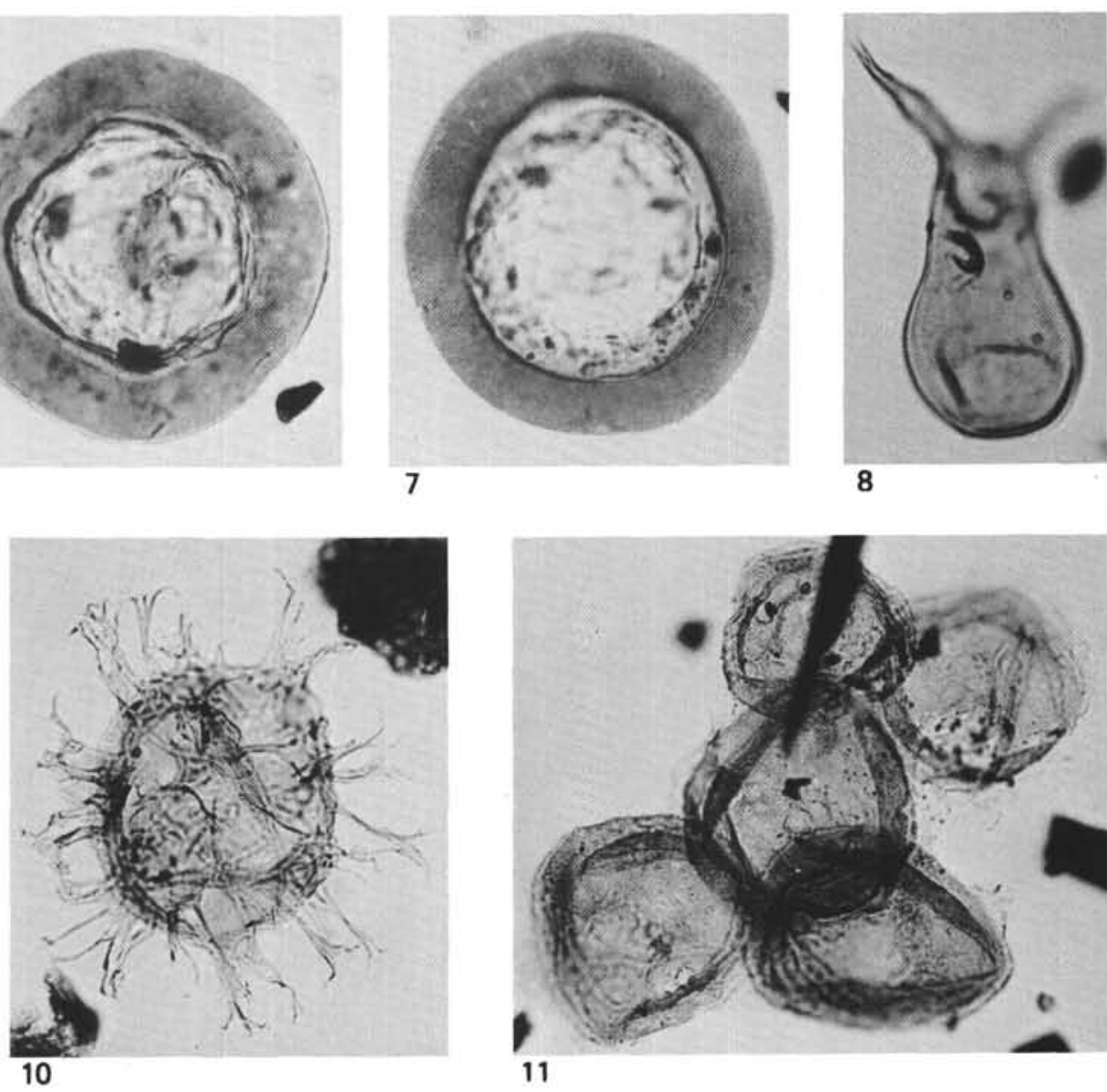

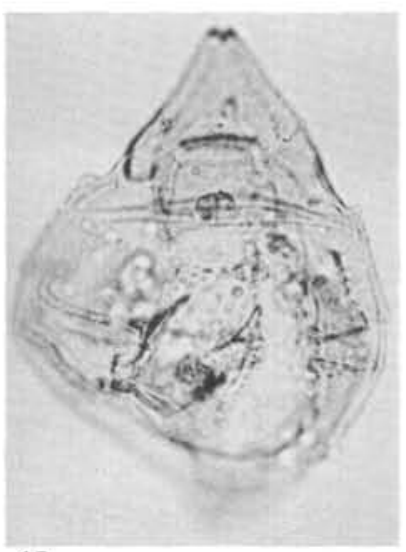

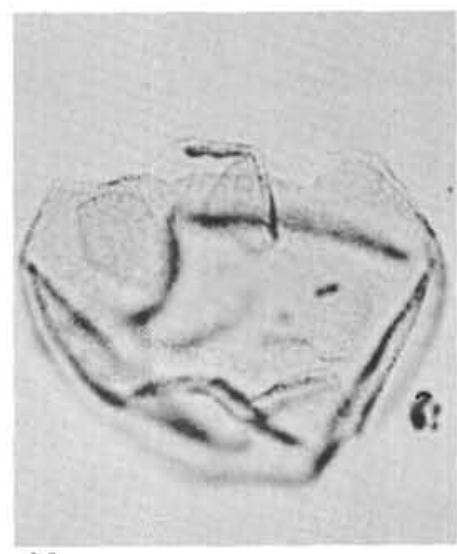

14

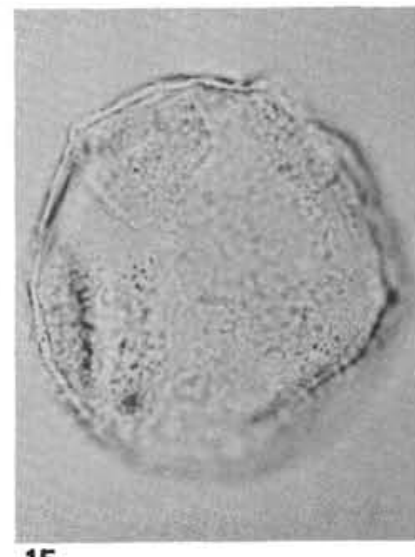

15 